\title{
Active faulting at the western tip of the Gulf of Corinth, Greece, from high-resolution seismic data
}

\author{
Arnaud Beckers a,b,*, Aurélia Hubert-Ferrari ${ }^{\text {a }}$, Christian Beck ${ }^{\mathrm{b}}$, Sarah Bodeux ${ }^{\mathrm{a}}$, Efthymios Tripsanas ${ }^{\mathrm{c}}$, \\ Dimitris Sakellariou ${ }^{\mathrm{c}}$, Marc De Batist ${ }^{\mathrm{d}}$ \\ a Department of Geography, University of Liège, Liège B-4000, Belgium \\ b ISTerre, CNRS UMR 5275, University of Savoie, Le Bourget du Lac F-73376, France \\ ' Institute of Oceanography, Hellenic Center for Marine Research, Anavyssos GR-19013, Greece \\ ${ }^{\mathrm{d}}$ Renard Centre of Marine Geology, University of Gent, Gent B-9000, Belgium
}

\section{A R T I C L E I N F O}

\section{Article history:}

Received 18 April 2014

Received in revised form 30 October 2014

Accepted 21 December 2014

Available online 3 January 2015

\section{Keywords:}

Corinth Rift

offshore faults

strike-slip fault

normal fault

seismic reflection

triple junction

extension

seismic hazard

\begin{abstract}
A B S T R A C T
The Gulf of Corinth is one of the fastest-spreading intra-continental rifts on Earth. GPS data indicate that the rift is currently opening in a NNE-SSW direction, with a rate of extension reaching up to $16 \mathrm{~mm} \mathrm{yr}^{-1}$ in its westernmost part. Although the rest of the offshore rift has been well studied, the western tip of the rift is still poorly explored. We present an accurate map of submarine faults in this area based on two high-resolution seismic reflection surveys (single-channel sparker). In the eastern part of the studied area, the sedimentary infill is affected by the known North Eratini, South Eratini, and West Channel faults. Further to the west, the seafloor is mostly flat and is bounded to the north by the normal, south-dipping, Trizonia fault. To the north, the shallower part of the Gulf shows to the east a diffuse pattern of normal and strike-slip deformation, which is replaced to the west by a $7.5 \mathrm{~km}$ long SE striking strike-slip fault zone, called the Managouli fault zone. To the westernmost tip of the Gulf, in the Nafpaktos Basin, two fault sets with different strikes are encountered; the one with a NE-SW strike exhibits a clear strike-slip component. The western tip of the Gulf of Corinth is the only part of the Corinth Rift where convincing evidence for strike-slip movement has been found. This fault pattern is likely related to the complex deformation occurring at the diffuse junction at the western tip of the Rift between three crustal blocks: Continental Greece, Peloponnese, and the Ionian Island-Akarnania block.
\end{abstract}

(c) 2015 Elsevier B.V. All rights reserved.

\section{Introduction}

The Gulf of Corinth is one of the most active intra-continental rifts on earth. This $120 \mathrm{~km}$ long, N120 E-trending structure separates the continental Greece to the north from the Peloponnese to the south (Fig. 1). Dating from uplifted syn-rift sediments covering the northern Peloponnese suggests that the rifting initiated around $5 \mathrm{Ma}$ ago (Kontopoulos and Doutsos, 1985; Collier and Dart, 1991). Since 1.8-1.5 Ma, the deformation migrated northward, in parallel with an increase of the extension rate (Ori, 1989; Sorel, 2000; Rohais et al., 2007; Ford et al., 2013). Concerning the tectonic controls on the rifting, it might result from the extension in the back-arc region of the Aegean subduction zone, enhanced by the interaction with the western tip of the North Anatolian Fault (Armijo et al., 1996, 2004; Jolivet, 2001; Hubert-Ferrari et al., 2003; Kokkalas et al., 2006; Reilinger et al., 2010; Pérouse et al., 2012). Except for its Western tip, i.e., west of the town of Aigion, the structure and evolution of the offshore rifting has been

\footnotetext{
* Corresponding author at: Bât. B11 Géomorphologie, allée du 6 Août 2, 4000 Liège, Belgium. Tel.: + 3243665255 .

E-mail address: beckersarnaud@gmail.com (A. Beckers).
}

reconstructed based on seismic reflection data (Stefatos et al., 2002; Leeder et al., 2002; Moretti et al., 2003; McNeill et al., 2005a; Lykousis et al., 2007a; Sakellariou et al., 2007a, 2007b; Bell et al., 2008, 2009; Taylor et al., 2011; Charalampakis et al., 2014). These studies have highlighted a complex basin structure (Bell et al., 2009) characterized by significant along strike variations associated to changes in the inherited basement fabric (Taylor et al., 2011). The deformation is currently localized on en-echelon north-dipping normal faults delimiting the southern coastline, as well as on $\mathrm{N}$ - and S-dipping offshore faults (Fig. 1) (Avallone et al., 2004).

The western tip of the Corinth Rift is characterized by the highest extensional rate (up to $16 \mathrm{~mm} \mathrm{yr}^{-1}$ ), and the geodetic measurements show that most of present-day deformation is concentrated offshore in a narrow band (Briole et al., 2000; Avallone et al., 2004). In this area, the southern coast is bounded by the en-echelon Eliki-AigionKamarai-Psathopyrgos fault system (Fig. 1). Late Quaternary slip rates of these faults have been estimated at about 1.9-2.7 $\mathrm{mm} \mathrm{yr}^{-1}$ (Kamari fault system), $0.3-2.0$ to $7-11 \mathrm{~mm} \mathrm{yr}^{-1}$ (Eliki faults), and $1.6-6.3$ to $9-11 \mathrm{~mm} \mathrm{yr}^{-1}$ (Aigion fault) based on the analysis of trenches (Koukouvelas et al., 2001, 2005, 2008; Pantosti et al., 2004; Palyvos et al., 2005) and uplifted shorelines combined with dislocation modeling 


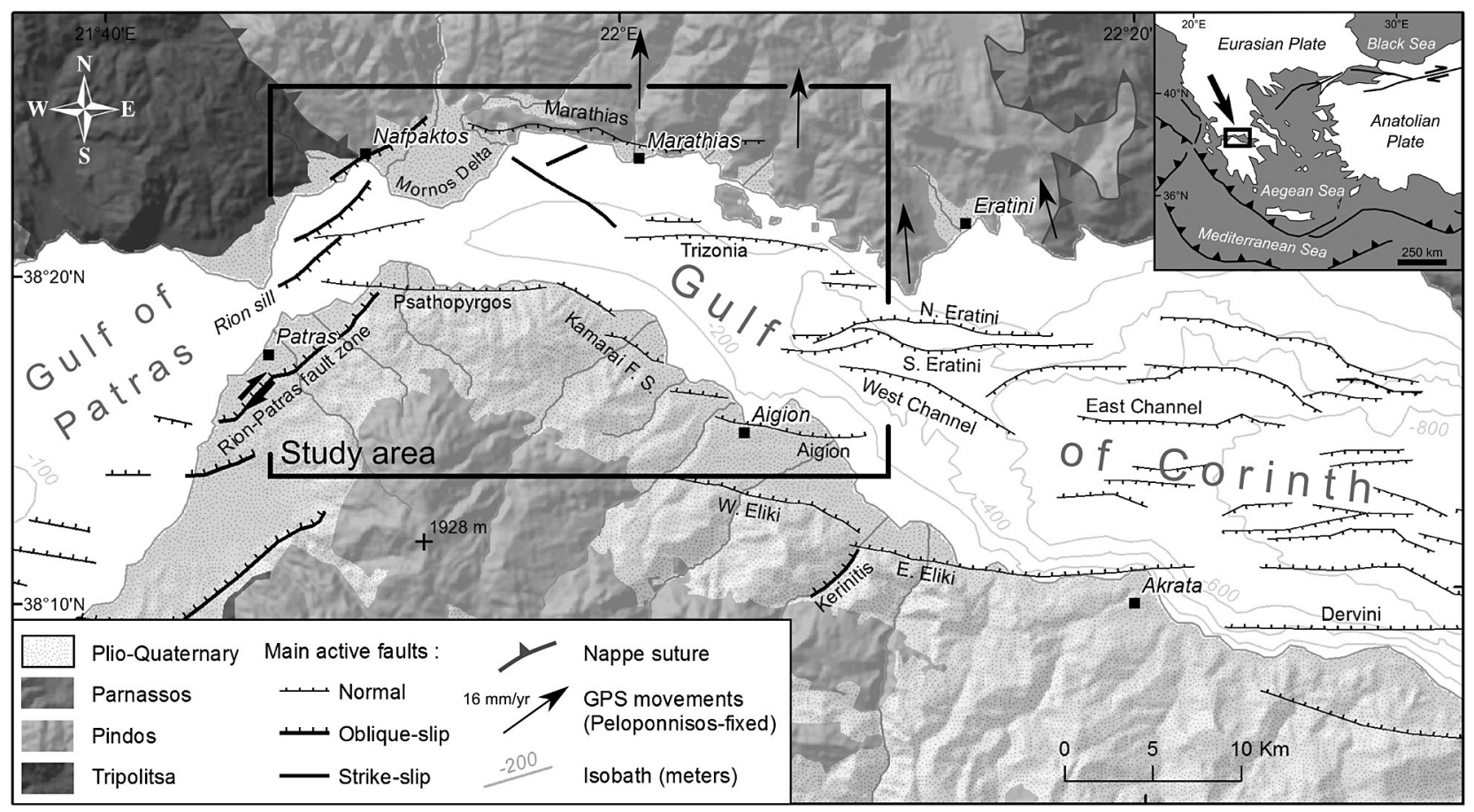

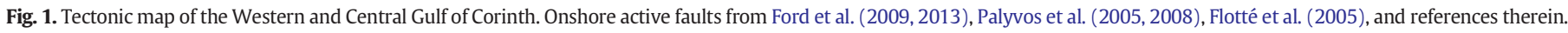

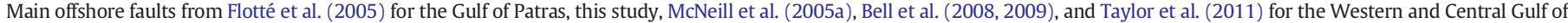
Corinth. Isobaths from Bell (2008). GPS displacement vectors from Avallone et al. (2004). Elevation: NASA SRTM DEM (http://srtm.csi.cgiar.org/).

(De Martini et al., 2004) or combined with seismic data (McNeill and Collier, 2004; McNeill et al., 2005b, 2007), and drilling (Cornet et al., 2004; Lemeille et al., 2004). On the northern coastline, the $14 \mathrm{~km}$ long Marathias fault has been mapped, but its activity has not been proven (Gallousi and Koukouvelas, 2007). Offshore, only sparse seismic data exist (Sakellariou et al., 2001, 2007b; Moretti et al., 2003; Bell et al., 2008). They allowed mapping four major faults: the West Channel, the South and North Eratini, and the Trizonia faults (Fig. 1). Bell et al. $(2008,2009)$ studied in detail the first three faults and estimated Late Quaternary slip rates of $\sim 0.5,1.0-1.9$, and $>1.4 \mathrm{~mm} \mathrm{yr}^{-1}$, respectively. The activity of the Trizonia fault is unknown, and its footwall is now subsiding at a rate of $5 \pm 2 \mathrm{~mm} \mathrm{yr}^{-1}$ according to GPS measurements (Moretti et al., 2003; Bernard et al., 2006). At depths greater than $5 \mathrm{~km}$, seismological studies have evidenced a fully asymmetrical extensional system, where deformation occurs on a horizontal or low-dipping zone of microseismicity linked to the north-dipping coastal fault system (Rigo et al., 1996; Lyon-Caen et al., 2004). This zone has been interpreted as the brittle-ductile transition (Hatzfeld et al., 2000), or as a crustalscale detachment (Jolivet et al., 2010), or as a newly formed blind detachment (Lambotte et al., 2014).

The present study aims to complete the fault map of the Corinth Rift at its Western tip, west of Aigion (Fig. 1), using a dense grid of highresolution seismic reflection data. These additional data are then used to investigate how this tectonic regime is accommodated in relationship with the Corinth Rift system toward the east, and the strike-slip faults highlighted around the Gulf of Patras toward the west. This is achieved by the development of (i) a seismo-chronostratigraphic model for the sedimentary infill, (ii) the analysis of the seafloor morphology, (iii) the production of a new map of active faults in the westernmost Gulf of Corinth and (iv) the assessment of their geodynamic implication at a regional scale.

\section{Previous chronostratigraphic model for the Gulf of Corinth}

Seismic profiles across the Gulf of Corinth show that the shallow sedimentary infill consists of a distinct alternation between seismic- stratigraphic units with parallel, continuous high-amplitude reflections and units with parallel, continuous low-amplitude reflections to acoustically transparent seismic facies (Bell et al., 2008, 2009; Taylor et al., 2011). Generally, the semi-transparent units are thicker than the highly reflective units (Taylor et al., 2011). These alternating seismicstratigraphic units have been observed throughout the Gulf of Corinth and have been interpreted as depositional sequences linked to glacioeustatic cycles (Bell et al., 2008, 2009; Taylor et al., 2011; Li et al., 2014). Because of the presence of the $62 \mathrm{~m}$ deep Rion Sill, the Gulf was disconnected from the World Ocean during Quaternary lowstands and was thus a non-marine sedimentary environment. The marine and non-marine environments are associated with different climatic regimes (Leeder et al., 1998, 2005; Collier et al., 2000). During glacial stages, the sparse vegetation cover was more favorable to erosion than during interglacials, so high quantities of sediments were routed towards the Gulf. These lowstand deposits appear as thick, lowreflective units. The thin, high-reflective units are interpreted to represent the marine highstand deposits. The change in reflectivity between seismic units could be due to variations in sediment density and velocity, but the sedimentological origin for this change is still unclear (Li et al., 2014). The last lacustrine-marine transition has been sampled in different sedimentary cores (Collier et al., 2000; Moretti et al., 2004; Lykousis et al., 2007a; Van Welden, 2007; Campos et al., 2013). This geomorphological setting and the consequences on the seismic stratigraphy are similar to the Gulf of Cariaco, NE Venezuela (Van Daele et al., 2011).

\section{Data acquisition and fault mapping}

Two high-resolution reflection-seismic surveys (sparker and singlechannel streamer) were performed aboard HCMR's R/V ALKYON in 2011 and 2012, within the framework of the SISCOR ANR Project (Fig. 2). The area covered lies between the Rion Sill to the west and the eastern extremity of the Aigion fault, to the east (Fig. 2). Our seismic lines tie with Bell et al.'s (2009) data set, therefore a direct correlation with our data set is possible and allows to estimate the age of our 


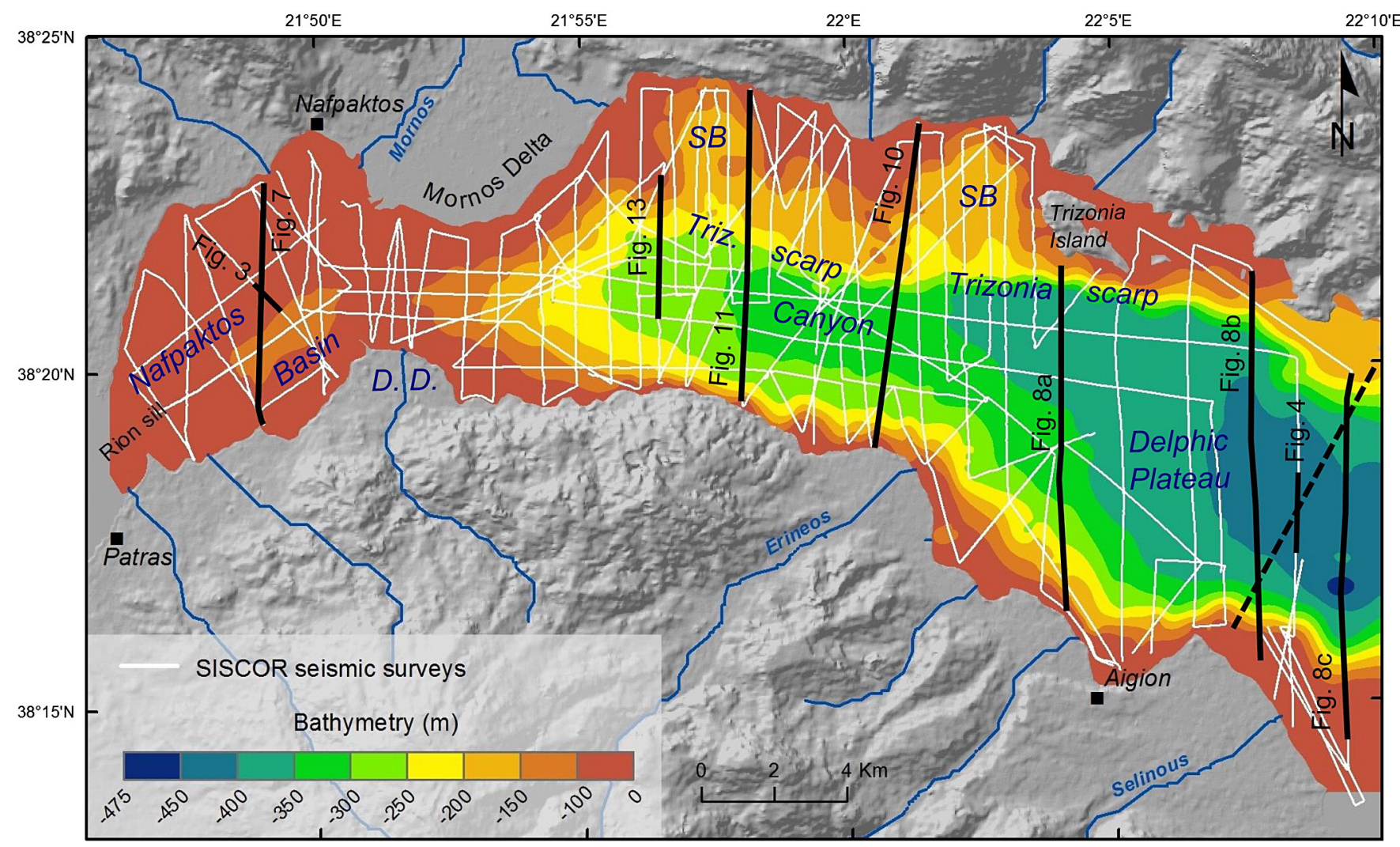

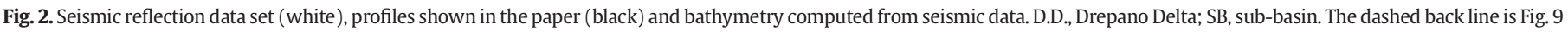
from Bell et al. (2008).

stratigraphy (Fig. 2). In total, $600 \mathrm{~km}$ of seismic lines have been acquired with RCMG's "Centipede" multi-electrode sparker. The sparker source produces a broad-spectrum seismic signal, with a mean frequency at $\sim 1.3 \mathrm{kHz}$. The expected vertical resolution at depth is $\sim 1 \mathrm{~m}$. A singlechannel, high-resolution streamer was used as receiver. A band-pass filter (200-300 to $2000-3000 \mathrm{~Hz}$ ) has been applied to eliminate nonsignal noise. The maximum penetration depth below the seafloor is about $360 \mathrm{~ms}$ two way travel time (TWTT) to the east and about $100 \mathrm{~ms}$ TWTT to the west, i.e., $270-360 \mathrm{~m}$ and 75-100 m, respectively. This did not allow imaging the basement, except on the margins. The decrease in penetration depth to the west occurs sharply at $\sim 22^{\circ} 01^{\prime}$ longitude $\mathrm{E}$ and is assumed to be related to the presence of coarser sediments or gas at shallow depth.

We used published bathymetric data to check if any of the identified faults had significant morphological expression at the seafloor and to identify the main sediment pathways (McNeill et al., 2005a; Cotterill, 2006; Nomikou et al., 2011). Because these data do not cover the whole study area, especially to the west, we also interpolated the seafloor depth data from the seismic lines (Fig. 2).

We considered every linear structure that offsets horizons within the sedimentary infill and extends up to the seafloor as an active fault. Steep contact surfaces between sedimentary infill and pre-rift basement were considered as faults only if Holocene sediments in the hanging wall thicken and reflections diverge toward the fault. Indeed, onshore studies in the Western Corinth Rift have shown that the top of the pre-rift basement is not a flat surface but is marked by an inherited relief up to $1000 \mathrm{~m}$ (Ford et al., 2013), and similar erosional slopes observed offshore may be misinterpreted as faults. The uncertainty in fault length measurement corresponds to the spacing between the seismic lines, namely, $\sim 1 \mathrm{~km}$ on average. To assess fault dip and vertical slip rates (the dominant component on most of the investigated faults), we have depth-converted our interpretation of some seismic profiles using two end-member velocities of 1.5 and $2.0 \mathrm{~km} \mathrm{~s}^{-1}$ according to the range provided by Bell et al. (2009) for the Western Gulf of Corinth. These two velocities have been applied successively to the imaged sedimentary infill to obtain a range of possible depths for some key reflectors. Slip rates have been estimated based on the offsets of these key horizons (reflectors or unit limits, see Section 4.2 for the seismic stratigraphy). In addition, for faults where the key horizons cannot be defined a minimum slip rate has been estimated using the local sedimentation rate. Indeed, where the seafloor is not subject to erosion (e.g., by bottom currents or large sediment density flows), the permanence of a fault scarp implies that the vertical slip rate exceeds the local sedimentation rate. The latter has been deduced from Holocene isopachs stemming from the interpretation of our seismic data (Holocene mean sedimentation rate, see Section 4.2 for the chronostratigraphic model) or from coring data (last century mean sedimentation rate, Beckers et al., 2013).

\section{Results}

\subsection{Seafloor morphology}

Fig. 2 displays the morphological units of the seafloor relief interpreted in this study. These different units will be commented from west to east. The Nafpaktos Basin is situated between the Rion Sill and the Mornos Delta, and it forms a SW-NE striking, 115 m deep depression centered $2 \mathrm{~km}$ offshore the south coast (Fig. 2). The seafloor relief is smooth, partly due to the action of marine currents, highlighted in the seismic data by erosional truncation at the seafloor (Fig. 3). Between the Mornos Delta and the Drepano Delta lies a second, $97 \mathrm{~m}$ deep sill, which is formed by the coalescence of the two deltas (Fig. 2). East of this sill, the morphology in the center of the Gulf consists of a $3 \mathrm{~km}$ wide, 300 to 430 m deep Canyon, widening and deepening in an eastward direction. Its steep southern edge corresponds to the Psathopyrgos and Kamarai faults (Fig. 1). More to the east, the Canyon becomes the Delphic Plateau (Heezen et al., 1966). The Delphic Plateau is bordered 


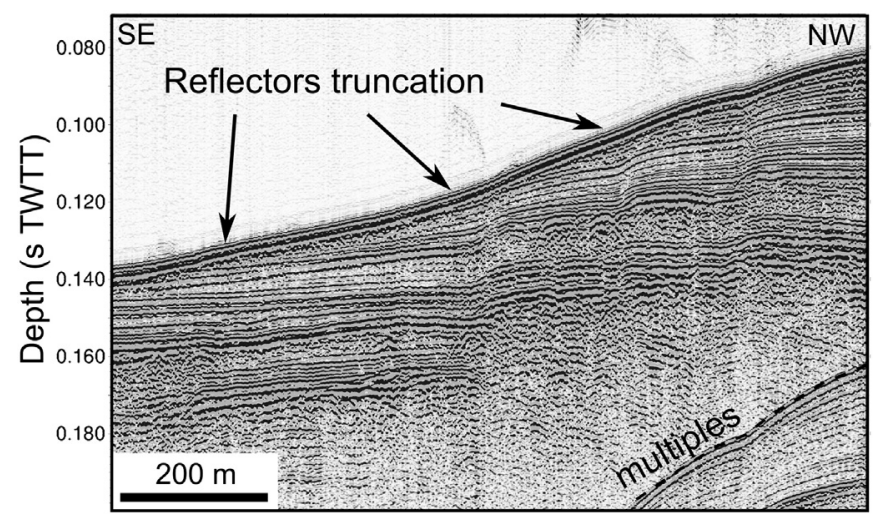

Fig. 3. SE-NW Sparker seismic profile in the Nafpaktos Basin showing seafloor erosion by present bottom currents. See Fig. 2 for its location. Vertical exaggeration $\times 7$.

to the south by steep slopes formed by Gilbert-type fan-delta foreset beds $\left(15^{\circ}\right.$ to $20^{\circ}$ dip, locally up to $30^{\circ}$ ) (Piper et al., 1990; Lykousis et al., 2007b, their Fig. 2) (Fig. 2). The Canyon and the Delphic Plateau are bounded to the north by a complex morphology, involving the W-E striking, $14 \mathrm{~km}$ long, Trizonia scarp and two main subhorizontal levels (Fig. 2). The upper level consists of a shelf with the edge located between 100 and $112 \mathrm{~m}$ depth. The shape of the shelf edge is irregular and delimits two sub-basins (173 and $190 \mathrm{~m}$ deep) that form the second subhorizontal level (SB, Fig. 2).

\subsection{Seismic stratigraphy}

The seismic stratigraphy of the Delphic Plateau, the Canyon, and the shallow nearshore areas is quite different. In the Delphic Plateau, the shallowest sedimentary unit is composed of high-amplitude subparallel reflectors (Fig. 4). The seismic facies characteristics of this highly reflective unit are similar to those of Holocene sediments documented by Bell et al. $(2008,2009)$ and Taylor et al. (2011) in the Gulf of Corinth, and the base of this unit (here named R1) correlates with the base of the Holocene interpreted by these authors (Fig. 4). Below
R1 the amplitude of the reflectivity sharply decreases (Fig. 4), which is a characteristic of lowstand deposits during the Last Glacial Maximum (LGM, or MIS 2) (Bell et al., 2008). The seismic facies encompasses sub-parallel, low-amplitude reflectors, alternating with thick, chaotic to acoustically transparent bodies. We interpret the first type of seismic facies to represent intercalations of turbidites and hemipelagites and the second seismic facies to be the result of thick mass transport deposits. Our data do not image any deeper extended highly reflective seismic units, despite a penetration depth of 270-360 m that should allow reaching the MIS 5 and MIS 7 highly reflective units described in the eastern Delphic Plateau by Bell et al. (2008). Those two units are only imaged in our easternmost profiles (Fig. 4) but are not identifiable westward. However, in the central and western Delphic Plateau, some strong reflectors exist and can be followed across a wide area (i.e., reflector 2: R2, Figs. 4 and 5). Despite that these reflectors do not delimit significant changes in seismic facies characteristics (Fig. 5Cand D), the comparison with the chronostratigraphy of Bell et al. (2008), linked to eustatic sea-level fluctuations (Section 2) shows that the strong reflector $\mathrm{R} 2$ corresponds to the $130 \mathrm{ka}$ glacial-interglacial boundary (Fig. 4). In summary, the data set of this study allows for the identification of two units in the Delphic plateau: the Holocene and the MIS 5 to 2 which bases are respectively called reflectors R1 and R2.

Following the Canyon westward, the high-amplitude reflections of the upper Holocene unit become discontinuous and are intercalated with hummocky to chaotic seismic units (Fig. 5B and C). The acoustic substratum is here reached at only $80 \mathrm{~ms}$ TWTT below the seafloor (Fig. 5B), but it does not coincide with the base of the sedimentary infill. Indeed, our data indicate locally a minimum sediment thickness of $275 \mathrm{~ms}$ TWTT, namely, 210-275 $\mathrm{m}$. The sharp decrease in the penetration depth in the Canyon prevents us from identifying the $\mathrm{R} 2$ reflector. The observed seismic facies probably correspond to gravity flows (turbidity currents and debris flows) coming from the Mornos Delta. Near the Mornos and the Drepano deltas, subhorizontal high-amplitude discontinuous reflectors exist below the Holocene foresets (Fig. 5A), which are interpreted to correspond to coarser-grained, lowstand deposits of the LGM.

Sedimentation in the shallow areas of the Nafpaktos Basin and north of the Trizonia Scarp is disconnected from the deep Gulf. Transgressive and highstand system tracks have been identified at the top of highly
Bell et al.'s (2008) interpretation

This study

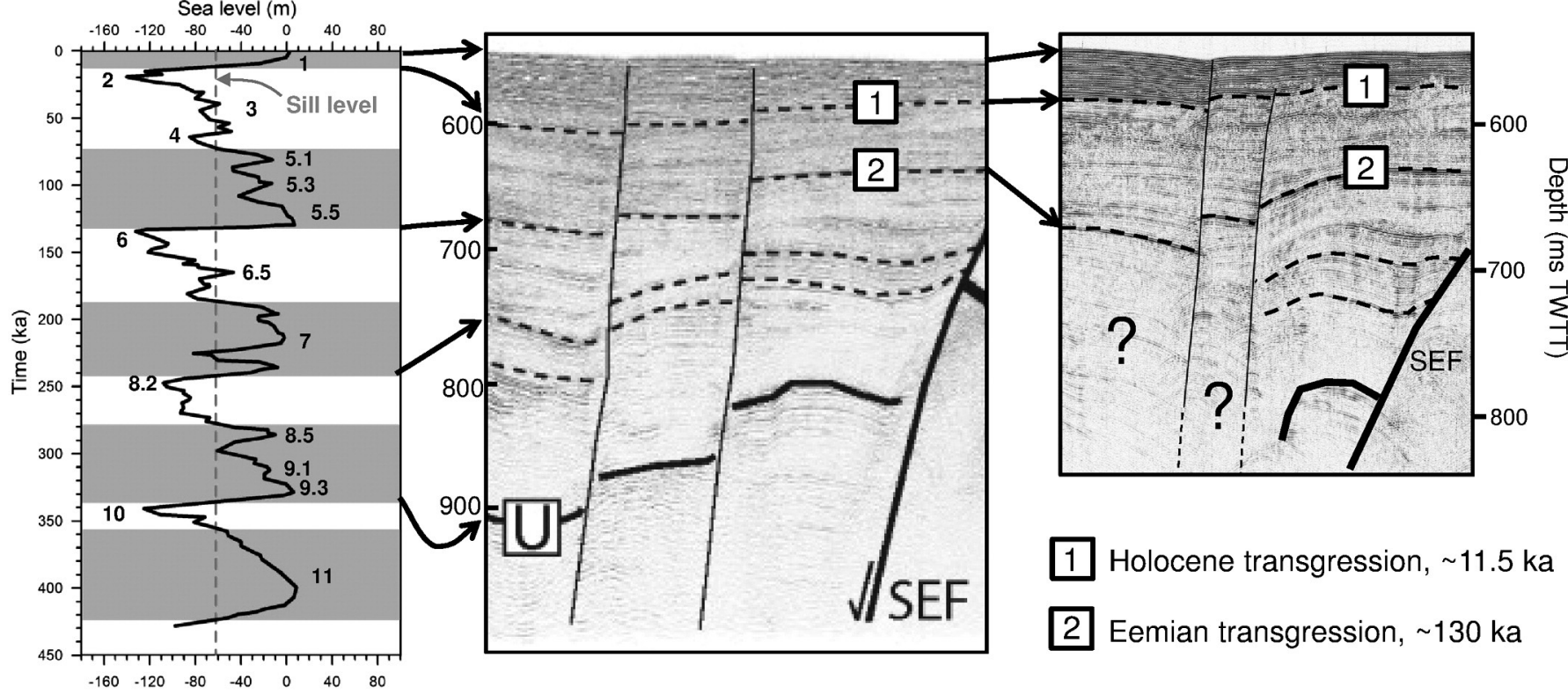

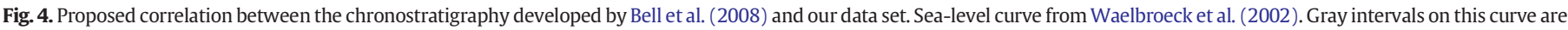

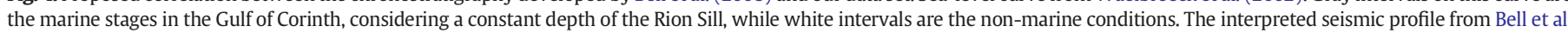
(2008) comes from their Fig. 9, localized in our Fig. 2. Age of the Holocene transgression in the Gulf of Corinth from Cotterill (2006). SEF: South Eratini fault. 

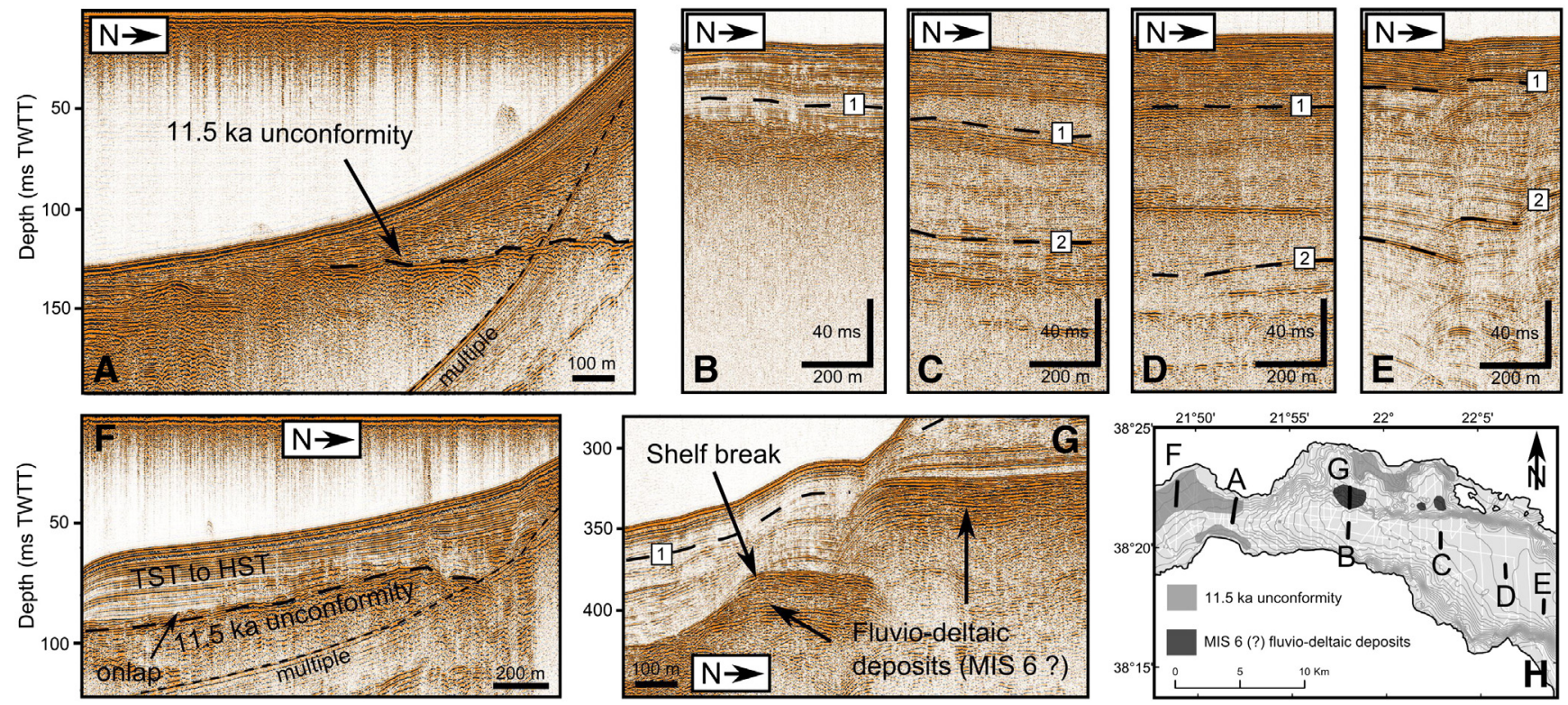

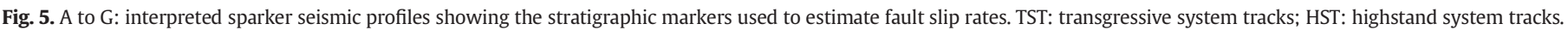

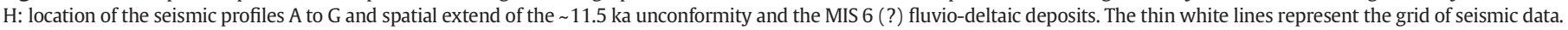

reflective surfaces (Fig. 5F) that are mapped in Fig. 5H. These surfaces are interpreted as transgressive Holocene surfaces developed on top of thick paleodeltas, probably built during the LGM lowstand. Such an interpretation is in agreement with previously published studies (Chronis et al., 1991; Collier et al., 2000; McNeill et al., 2005a; Cotterill, 2006; Lykousis et al., 2007a; Sakellariou et al., 2011). North of the Trizonia Scarp, below these deltas, an older fluvio-deltaic system located 38 to $50 \mathrm{~m}$ below R1 is identified (Fig. 5G and H). It is inferred that these deltas were deposited during a previous lowstand episode, probably during MIS 6.

\subsection{Active faulting and deformation}

We have identified three different fault systems: the Nafpaktos fault system in the west, the Trizonia fault system (TZFS) in the north, and the termination of the Eratini-West Channel fault system in the east. The submarine fault systems that we have interpreted are shown in Fig. 6, and below we describe this fault network from the fault F1 to F15. Slip rates have been estimated for all the significant faults (listed in Table 1).

At the western end of our study area, close to the Rion Sill, no active faults have been identified; however, seismic data in this area are poor

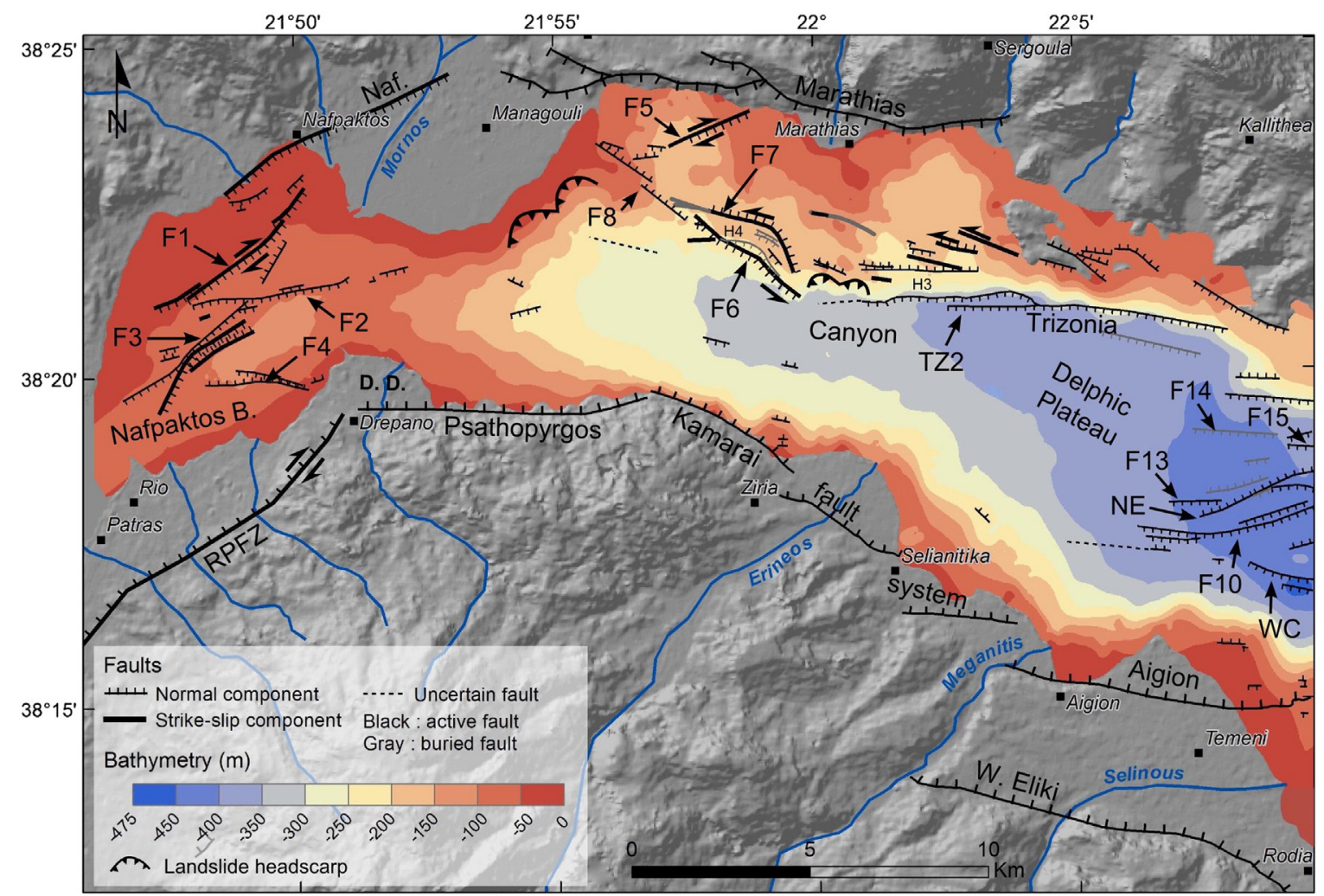

Fig. 6. Map of offshore faults identified in this study. Onshore faults from Ford et al. (2009, 2013), Palyvos et al. (2005, 2008), Flotté et al. (2005), and references therein. 
Table 1

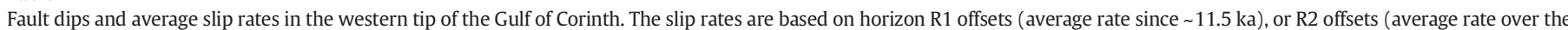
last $\sim 130 \mathrm{ka}$ ) or based on the present-day mean sedimentation rate. Slip rates have been measured in the center of the fault, except where mentioned explicitly.

\begin{tabular}{|c|c|c|c|c|}
\hline Fault name, type & $\begin{array}{l}\text { Dip angle } \\
\left({ }^{\circ}\right)\end{array}$ & $\begin{array}{l}\text { Slip rate (norm. comp.) } \\
\left(\mathrm{mm} \mathrm{yr}^{-1}\right)\end{array}$ & $\begin{array}{l}\text { Hanging wall subsidence } \\
\left(\mathrm{mm} \mathrm{yr}^{-1}\right)\end{array}$ & Method used for slip rate assessment \\
\hline F1, oblique-slip & $\sim 90$ & $1.3-2.1$ & - & Offset R1 \\
\hline F2, normal & $\sim 90$ & $1.8-2.9$ & - & Offset R1 \\
\hline F1 + F2 + F3, normal/oblique-slip & $\sim 90$ & 2.7-4.2 (cumulated) & - & Offset R1 \\
\hline F5, oblique-slip & $?$ & $>1.5$ & - & Sedimentation rate core TRZ03, Beckers et al. (2013) \\
\hline F6, oblique-slip & $64-72$ & $0.4-0.5$ & - & Offset delta $130 \mathrm{ka}$ \\
\hline F8, normal & $?$ & $>1.5$ & - & Sedimentation rate core TRZ03, Beckers et al. (2013) \\
\hline Marathias, normal & $\begin{array}{l}\text { Not imaged in the } \\
\text { seismic data }\end{array}$ & - & $2.6-3.6$ & Depth of the 11.5 ka shelf break \\
\hline Marathias F. + F6 + F7, normal + oblique-slip & - & - & $1.6-1.7$ & Depth of the 130 ka shelf break \\
\hline TZ2, normal & $63-71$ & $0.36-0.44$ & - & Offset R2 \\
\hline West Channel, normal & $?$ & $>0.7$ (western tip) & - & Local Holocene sedimentation rate \\
\hline F10, normal & $65-74$ & $0.9-1.4$ (central part) & - & Offset R1 \\
\hline F10, normal & $55-66$ & $0.5-0.8$ (western tip) & - & Offset R1 \\
\hline North Eratini, normal & $39-52$ & $0.17-0.23$ (western tip) & - & Offset R2 \\
\hline F13, normal & $77-82$ & $0.1-0.2$ & - & Offset R1 \\
\hline F15, normal & Var. with depth & $>1.5$ & - & Local Holocene sedimentationrate \\
\hline
\end{tabular}

and the penetration depth is low. In the Nafpaktos Basin, the dominant deformation pattern is characterized by oblique extension accommodated mostly by SE dipping faults. Two different fault populations cross each other in the center of the basin and define a stair case morphology from the northern coast to the deepest part of the basin (Figs. 6 and 7). In the west and the north, the fault set strikes parallel to the Rion-Patras fault zone and is composed of two distinct fault zones, called F1 and F3. The spatial arrangement of the F3 fault zone looks like the surface expression of a flower structure with close parallel and antithetic strands (Fig. 6). The $5.5 \mathrm{~km}$ long F1 fault zone exhibits possible strike-slip motion, which is deduced from the pattern of near fault deformation of reflectors in the hanging wall (Fig. 7). They are deformed in opposite directions, which cannot be explained with a simple normal component of slip. Another observation that suggests this fault may have a strike-slip component is the high dip of the fault, which appears near vertical in the upper 55-75 m below seafloor that we have imaged. Those characteristics have also been observed on some strands of the F3 fault zone (Fig. 6). The other fault set strikes roughly E-W, parallel to the Psathopyrgos fault. It is composed of the $6 \mathrm{~km}$ long F2 fault and the F4 strand, which is interpreted as the western tail of the Psathopyrgos fault (Figs. 6 and 7). Our data do not indicate any strikeslip movement on these two faults. The F3 fault zone terminates to the north on the F2 fault zone.

The base of the Holocene, i.e., Reflector 1, has been identified in the shallowest northern part of the basin (Fig. 5F and $\mathrm{H}$ ), allowing an estimation of the vertical component of the average slip rate for F1, F2, and F3. The Holocene rate reaches $1.3-2.1 \mathrm{~mm} \mathrm{yr}^{-1}$ for the central part of F1 and 1.8 to $2.9 \mathrm{~mm} \mathrm{yr}^{-1}$ for F2 (Fig. 7). The cumulated vertical slip rate for all the south-dipping strands (Fig. 7) is between 2.6 and $4.2 \mathrm{~mm} \mathrm{yr}^{-1}$.

East of the Mornos Delta, the main offshore structure is the TZFS (Sakellariou et al., 2001, 2007b). Inside the Canyon and on the southern slopes, only minor faults have been identified. The TZFS occupies the northern half of the Gulf and consists of the F6, F7, F8, and Trizonia faults (Fig. 6). The active Trizonia fault runs for about 10 to $11.5 \mathrm{~km}$ along the eastern part of the Trizonia scarp (Fig. 6). The eastern end of the Trizonia fault is well constrained by our data set, but the exact location of its western tip is masked by slope instabilities (Fig. 6). This fault shows

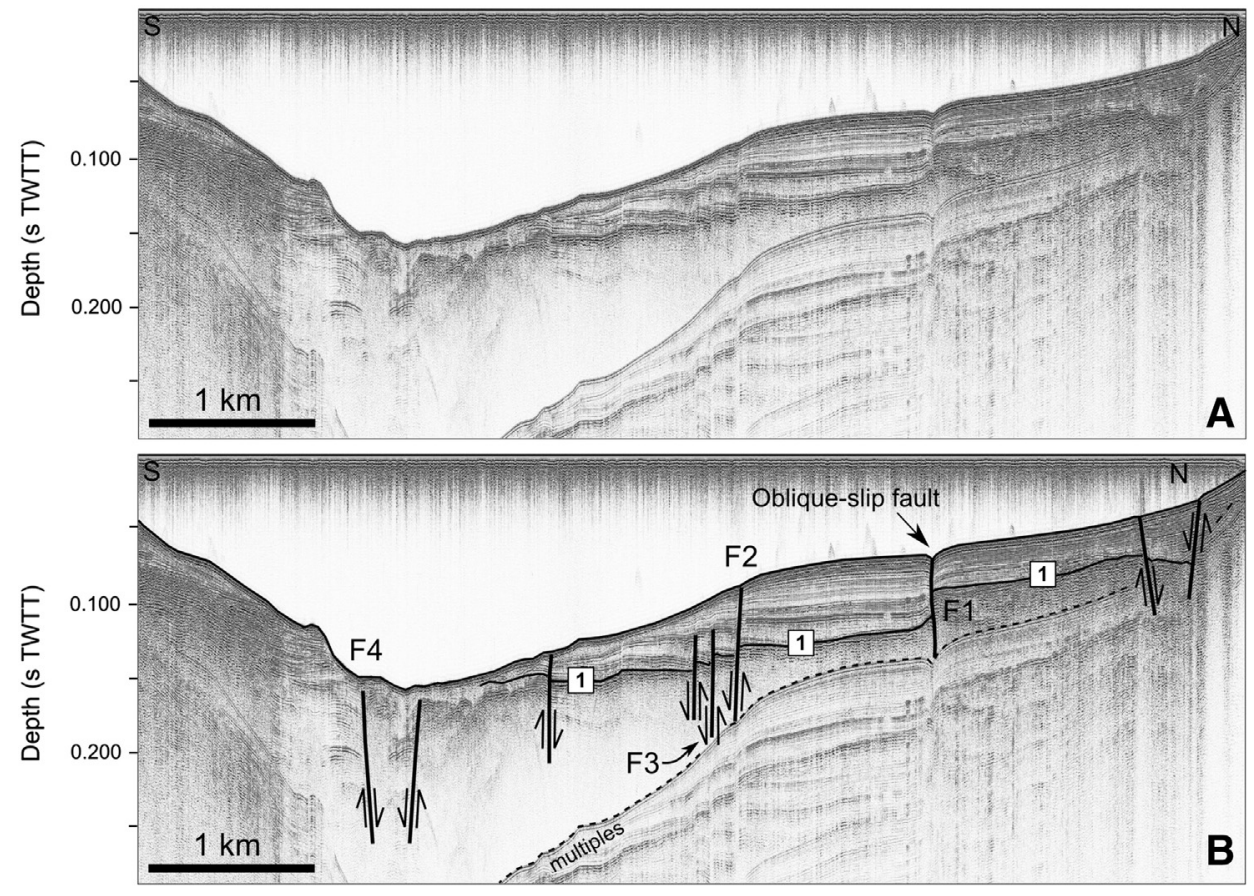

Fig. 7. S-N Sparker seismic profile in the Nafpaktos Basin. See Fig. 2 for its location. Horizon $1=11.5$ ka, after Bell et al. (2008). Vertical exaggeration $\times 12$. A: data, B: interpretation. 
two close splays (Figs. 6, 8A, and 9A). The main strand is located at the contact between the basement and the sedimentary infill. The secondary parallel splay, TZ2, cuts across the sedimentary infill with a $70^{\circ}$ dip (Fig. 9A). R2 can be identified in this area which allows the assessment of an average post-130 ka slip rate of $0.36-0.44 \mathrm{~mm} \mathrm{yr}^{-1}$ based on the offset of R2. Due to uncertainties on the depth of horizon R1 north of the fault, no Holocene slip rate has been assessed. To the south of the Trizonia fault, no other significant fault cuts the Delphic Plateau seafloor. In that area, R1 and R2 appear broadly subhorizontal, indicating overall a symmetric subsidence (Fig. 9A). This observation suggests that the activity of faults bordering both the north and south sides of the Western Gulf is similar. The deformation pattern changes west of the Trizonia fault. The profile in Fig. 10, which crosses the Gulf west of the Trizonia fault, shows that at this location sediments thicken to the south, implying asymmetrical deformation dominated by the activity of the north-dipping faults bounding the Gulf to the south.

North of the Trizonia fault, numerous short faults deform its footwall (Fig. 6). They define a left-stepping array showing normal as well as strike-slip motions. The normal faults bound a series of narrow horsts. The main one, i.e., H3, extends over $4 \mathrm{~km}$ west of the Trizonia Island
(Fig. 6). The documented strike-slip faults trend NW-SE and are located west of Trizonia Island.

West of the Trizonia fault, the Trizonia scarp is arranged in tiers that are partially controlled by a set of NW-SE trending transtensive faults, i.e., F6 and F7, delimiting a horst, i.e., H4 (Figs. 6 and 11). The southdipping F6 fault breaks off a paleodelta and exhibits a strike-slip component at its eastern end (Fig. 6). We infer that this paleodelta corresponds to the MIS 6 lowstand ( $140 \mathrm{ka})$. This interpretation implies a slip rate of $0.4-0.5 \mathrm{~mm} \mathrm{yr}^{-1}$ for this fault (67-73 ${ }^{\circ} \mathrm{dip}$ ) based on offset stratigraphy, and a mean subsidence rate of 1.6 to $1.7 \mathrm{~mm} \mathrm{yr}^{-1}$ of the delta rollover point assuming a water surface at $-62 \mathrm{~m}$ and a rollover point formation at -5 to $-10 \mathrm{~m}$ water depth (Lykousis et al., 2007a). Fig. 5G shows that the considered rollover point do not clearly separate topsets from foresets, as expected in a typical Gilbert-type delta. We propose that the absence of foresets is due to their erosion by submarine landslides, as presently observed in many Holocene deltas in the Western Gulf. The north-dipping F7 fault also exhibits strike-slip motion (Fig. 12). In addition to the criteria defined in the Nafpaktos Basin, strike-slip motion on this fault has been proposed based on other grounds. First, individual reflections either side of the fault show
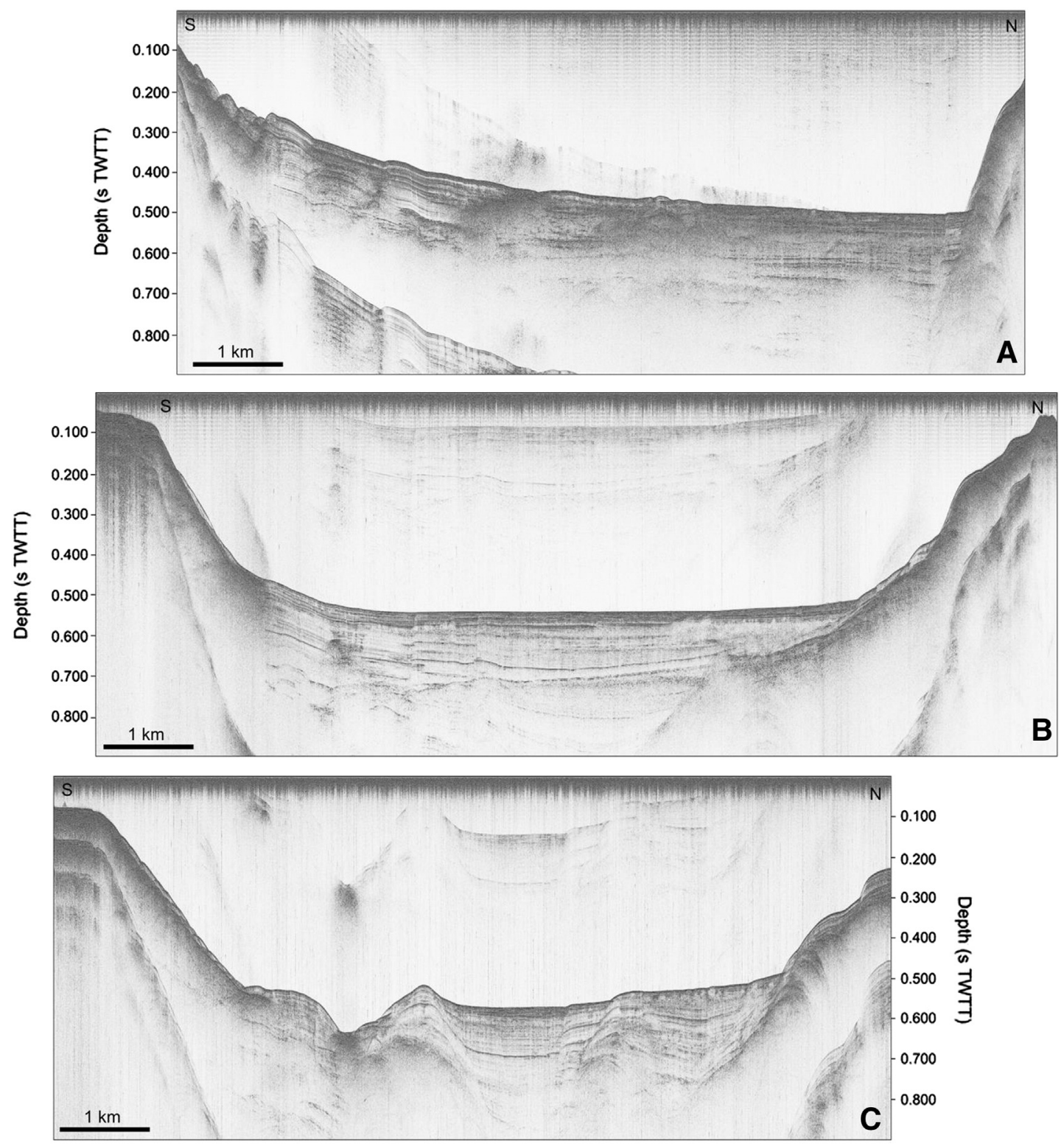

Fig. 8. Non-interpreted S-N Sparker seismic profiles of the eastern part of the study area. See Fig. 2 for its location. Vertical exaggeration $\times 6$. 

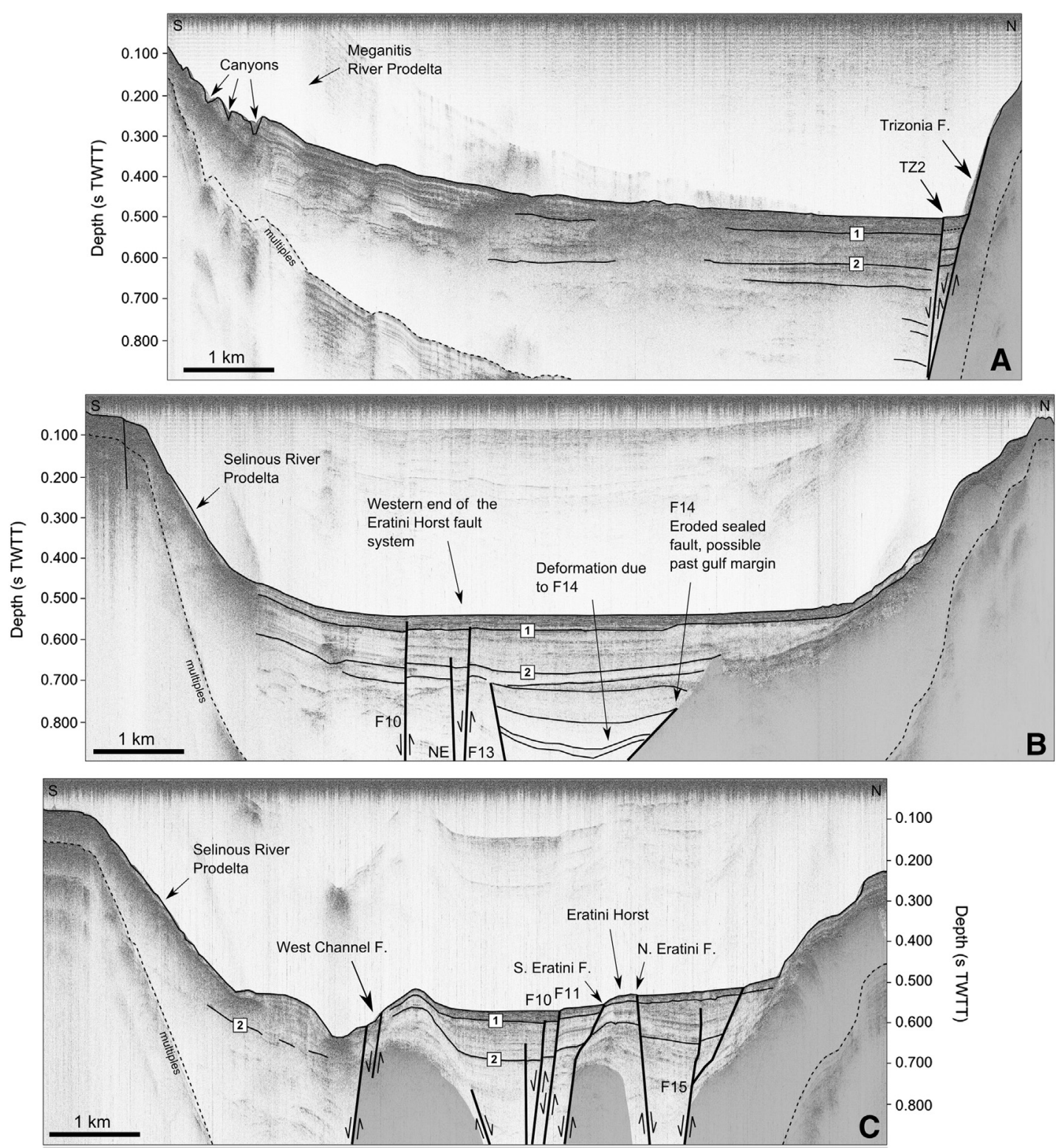

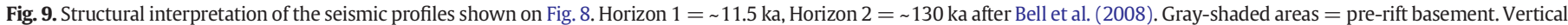
exaggeration $\times 6$.

opposite senses of offset with depth (Fig. 12). This observation cannot be explained by a simple normal component of slip. Additionally, individual reflections are very difficult to correlate between footwall and hanging wall, suggesting that they may be laterally offset (Fig. 12). West of the horst H4, the Trizonia scarp is not controlled by active faults (Figs. 2 and 6). However, an inherited $\sim 400 \mathrm{~m}$ high basement hill exists and appears to control the location of the scarp (Fig. 13). This relief could have initially been linked to a fault (dotted line in Fig. 13 and in Fig. 6, 1.5 km south of F8), during an older phase of the rift history, but no clear evidence for Holocene activity has been observed. Just north of the scarp, a $3.4 \mathrm{~km}$ long north-dipping normal fault, F8, composed of two segments, is aligned with the faulted H4 horst. The F6, F7, and F8 faults define a $7 \mathrm{~km}$ long, NW-SE striking fault zone between the Mornos delta and the Trizonia fault, which we name the Managouli fault zone. The fault pattern and the strike-slip components highlighted on F6 and F7 allow us to interpret it as the surface expression of a transtensive fault.

Between the NW-SE trending Managouli fault zone and the E-W trending Marathias fault, the F5 fault exhibits a NE-SW strike and strike-slip component. In its central part, the fault appears as a south-dipping normal fault with an associated $12 \mathrm{~m}$ high scarp, while $500 \mathrm{~m}$ more to the west, the apparent displacement is inverted, the top of the northern block being about 2 m lower than the southern one. The western tip of F5 forms a small graben bending toward F8. This F5 fault probably accommodates part of the complex deformation occurring at the intersection of the Managouli fault zone with the Marathias fault. The subsidence rate related to the Marathias fault can be inferred based on the rollover points of the LGM-associated deltas, which now occur at around $100 \mathrm{~m}$ b.s.l., which implies a 2.6-3.6 $\mathrm{mm} \mathrm{yr}^{-1}$ subsidence rate.

Southeast of the Trizonia fault, the sediments of the deep Gulf are affected by E-W striking normal faults belonging to the Eratini-West Channel fault system studied by Bell et al. (2008, 2009) (Fig. 9B and $C$ ). Three parallel $\sim \mathrm{E}-\mathrm{W}$ trending fault-bounded horsts divide the Delphic Plateau. The northern one is a bedrock horst on the margin of the Gulf, while the Eratini and West Channel Horsts are localized in the deep Gulf and are draped by sediments. In the graben, between the bedrock horst and the Eratini horst, three buried faults exist. Among them, the south-dipping F14 show a very low dip angle (16 to $24^{\circ}$, Fig. 9B). The past activity of this fault is inferred from the sediment 


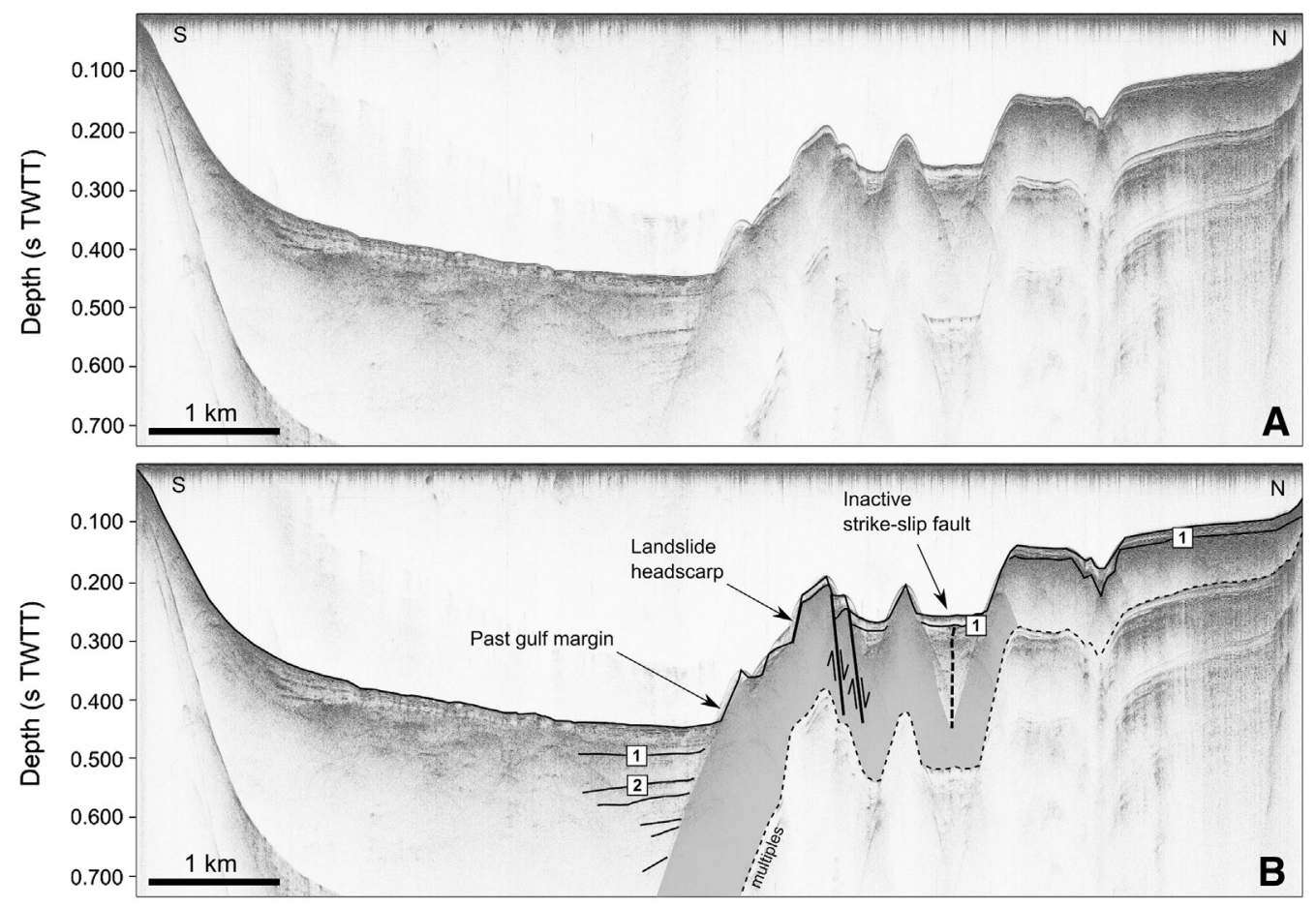

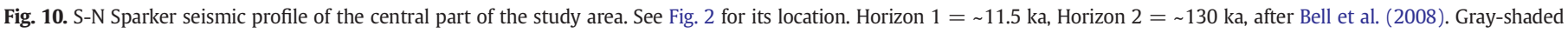
areas $=$ pre-rift basement. Vertical exaggeration $\times 6$. A: data, B: interpretation.

deformation visible at a depth of 220 ms TWTT and more below the seafloor (Fig. 9B). The absence of deformation of horizon R2 points out that the fault has been inactive for at least $130 \mathrm{ka}$. The very low dip angle of this fault could be due to fault plane erosion in aerial conditions, which suggests that this fault may have defined the northern margin of the Gulf more than 130 ka ago. East of this inactive F14 fault, the western tip of an active fault is imaged (F15, Fig. 9C). The length and the accurate strike of this fault are impossible to constrain from our data set. The Eratini horst appears in the morphology only on the easternmost profile (Fig. 9C), while it is buried to the west. Most of the deformation occurs to the south, along the $5 \mathrm{~km}$ long south-dipping F10 fault. Its slip rate varies from $0.5-0.8 \mathrm{~mm} \mathrm{yr}^{-1}$ (west) to $0.9-1.4 \mathrm{~mm} \mathrm{yr}^{-1}$ (center), based on the offset of reflector R1. Just south of the F10 fault, a northdipping normal fault is imaged in the Selinous prodelta in one seismic

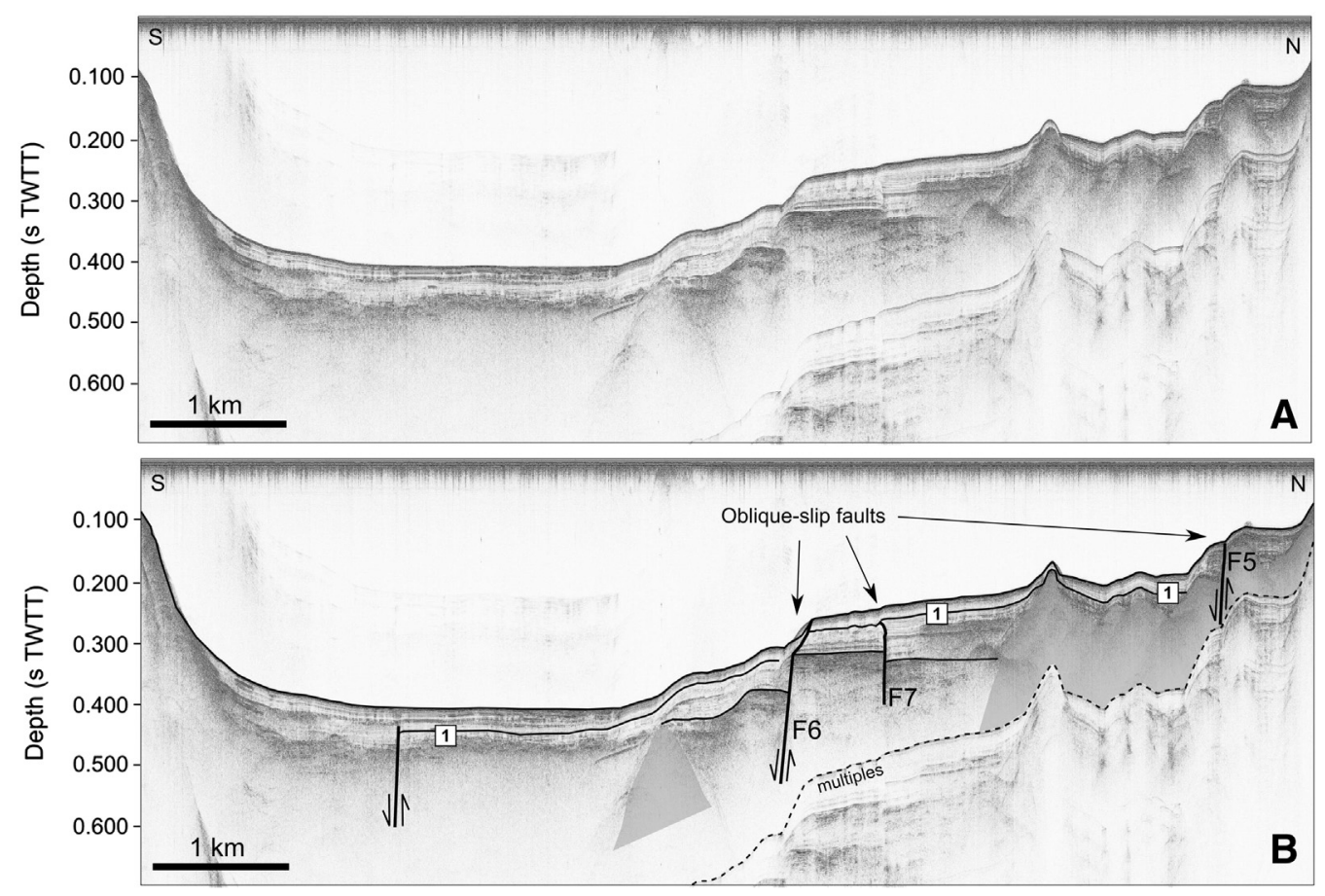

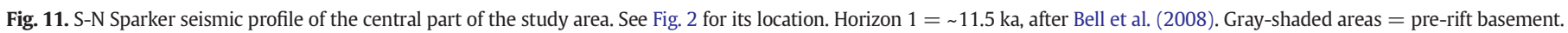
Vertical exaggeration $\times 6$. A: data, B: interpretation. 

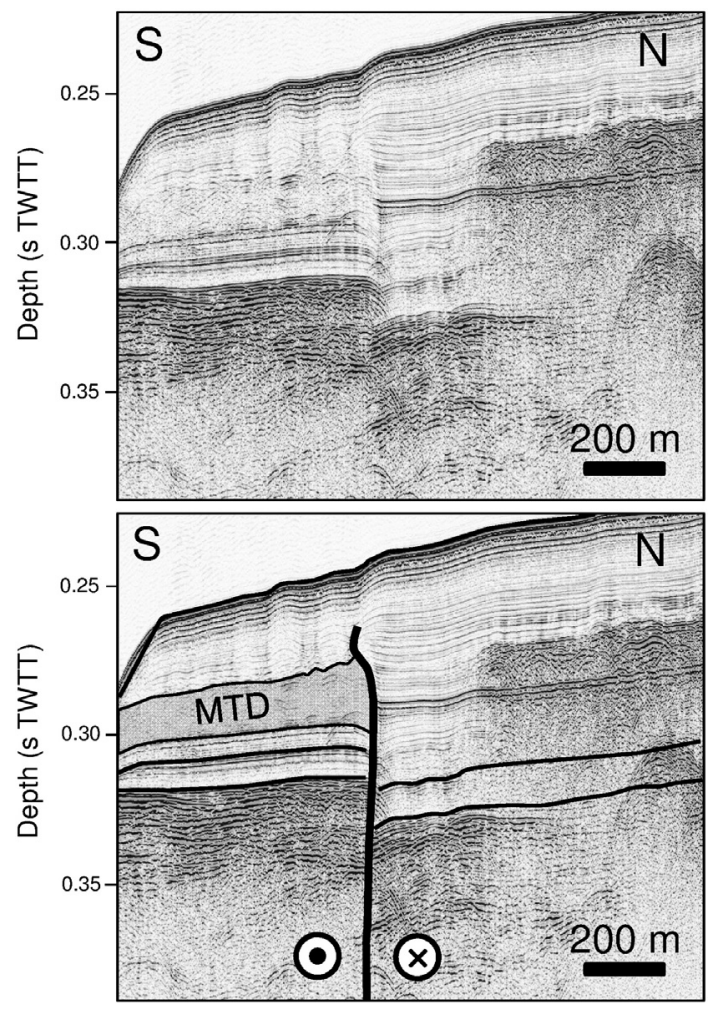

Fig. 12. Detailed view of Fig. 11 highlighting the strike-slip/oblique-slip fault F7. The sinistral movement is inferred from the regional stress field. Vertical exaggeration $\times 10$. Top: data, bottom: interpretation. MTD = mass transport deposit.

line, but its extension is unknown (Fig. 6). The last active fault system is the western tip of the West Channel fault (Fig. 9C), controlling the location of the eponymous horst.

\section{Discussion}

\subsection{Strike-slip motion in the Corinth Rift}

The data presented here show for the first time clear evidence of strike-slip motion on offshore faults in the Gulf of Corinth from seismic data. These faults are located between the Psathopyrgos and the Marathias faults (i.e., the Managouli fault zone) and in the Nafpaktos Basin (i.e., F1 and some strands of F3) (Fig. 6). Analyses of the microseismicity in these areas have also revealed strike-slip deformation in this part of the Corinth Rift. Hatzfeld et al. (2000) documented pure strikeslip and oblique-slip earthquake focal mechanisms in the Nafpaktos Basin (see their Fig. 10 with their whole data set and our Fig. 14 for one event of $\left.M_{\mathrm{W}}>4\right)$. Strike-slip motions at shallow depth ( $\left.<10 \mathrm{~km}\right)$ in that area have also been revealed by the aftershocks of the 2010 $M_{\mathrm{W}} 5.3$ Efpalion earthquake, even though the two main shocks showed pure-normal motions (Sokos et al., 2012, their Fig. 4, and our Fig. 14 for events of $M_{\mathrm{W}}>4$ ). In addition, some of these aftershocks showing a strike-slip focal mechanism are aligned with the Managouli fault zone. Close to Aigio, the main shock of a seismic swarm that occurred in 2001 indicated normal faulting with a strike-slip component (Fig. 14, Pacchiani and Lyon-Caen, 2010; Lambotte et al., 2014). This shock has been associated to a NW-dipping fault previously considered as inactive, the Kerinitis fault (KER, Fig. 14). In summary, although most of the largest faults of the Western Gulf of Corinth are pure-normal faults, this study shows evidence for strike-slip motions on at least three major offshore faults, and this result agrees with strike-slip and oblique-slip earthquake focal mechanisms occurring in a wide area between the Kerinitis fault and the Rion sill.

\subsection{Along strike changes in rift structure and rift polarity}

Several studies have been devoted to the mapping of offshore faults in the Gulf of Corinth (Stefatos et al., 2002; Moretti et al., 2003; McNeill et al., 2005a; Lykousis et al., 2007a; Sakellariou et al., 2007a, 2007b; Bell et al., 2008, 2009; Taylor et al., 2011; Charalampakis et al., 2014). This study at the western tip of the Gulf results in the completion of the fault map, up to the Rion sill to the west (Fig. 15). The relatively low penetration of acoustic waves used in this area does not allow us to estimate the age of the deformation. However, the observed structure and the spatial changes in rift polarity over the Late Quaternary period $(0-130 \mathrm{ka})$ can be compared to the ones described in the other parts of the rift. At a regional scale, the present physiography of the Gulf implies an asymmetry between the northern subsiding coastline and the southern uplifting margin. This asymmetry has been confirmed at the time scale of the whole gulf history by the southward dip of its basement (Taylor et al., 2011). However, the Late Quaternary isochore map (3rd sequence of Taylor et al., 2011) and seafloor morphology show a more complex pattern of subsidence with several along strike changes in rift polarity (Fig. 15).

In the easternmost rift sector, the Alkyonides Gulf is dominated by $\mathrm{N}$-dipping faults located along its south edge (Sakellariou et al., 2007a) while in the Lechaion Gulf, the system is inverted with sediment strata dipping to the north (Charalampakis et al., 2014) (Fig. 15). Northwest of the Perahora peninsula, a local depocenter is located in a midbasin sag. This implies space accommodation by extension in the basement without a simple relationship with faults cutting the seafloor (Taylor et al., 2011). In the eastern and central sectors, the Late Quaternary subsidence is roughly symmetric (Taylor et al., 2011). The next change in rift structure and polarity occurs between the central and the western sectors. In this latter part, the Gulf is shallower and the seafloor relief is marked by the Eratini and West Channel horsts (Bell et al.,
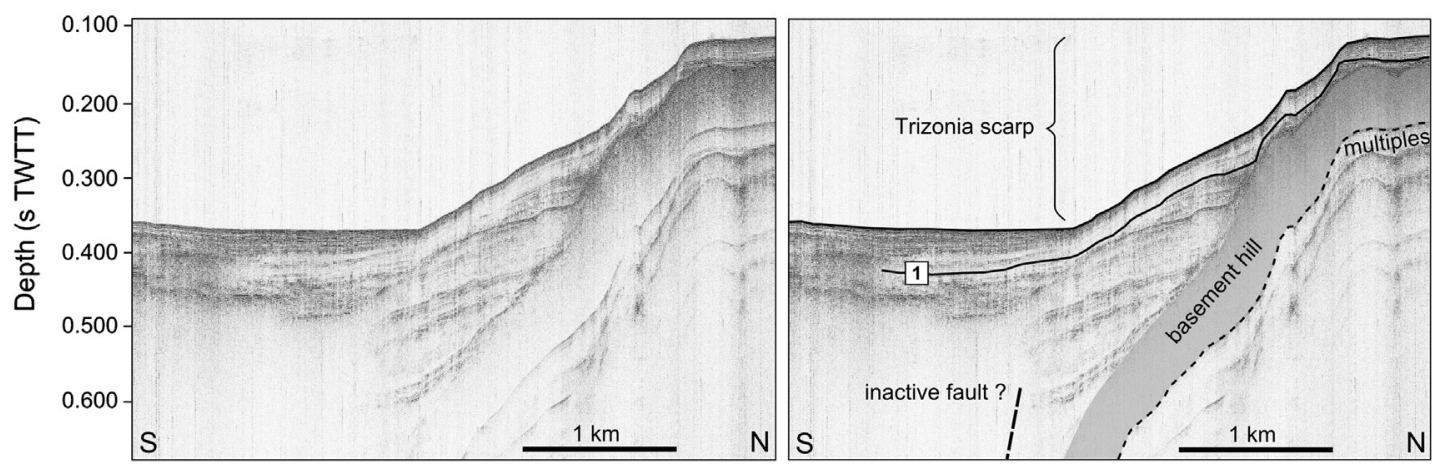

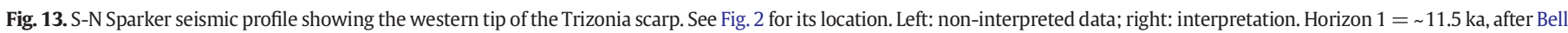
et al. (2008). Gray-shaded areas $=$ pre-rift basement. Vertical exaggeration $\times 6$. A: data; B: interpretation. 


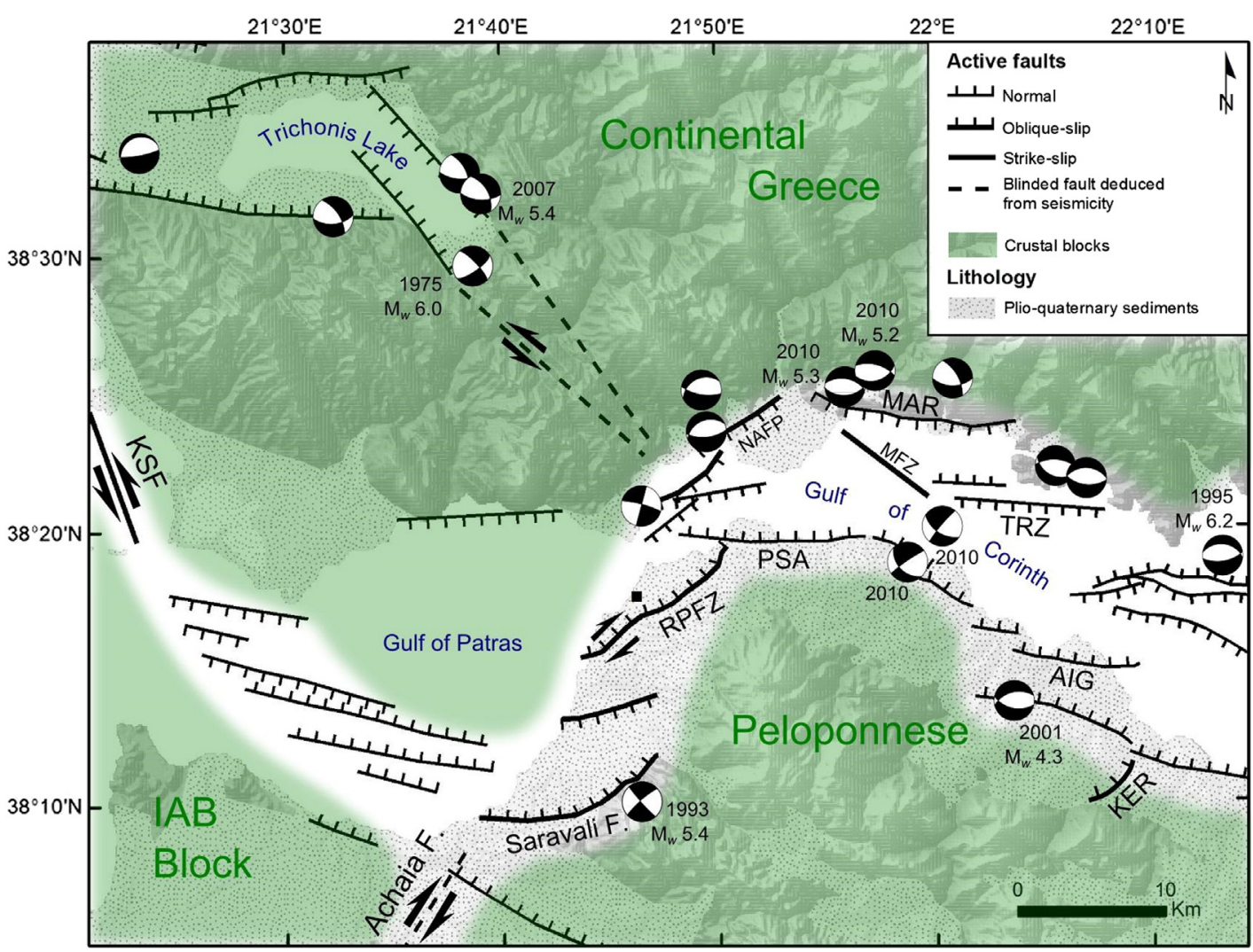

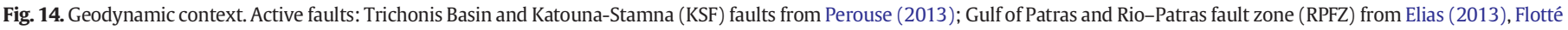

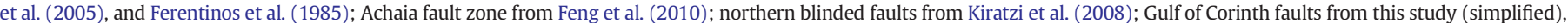

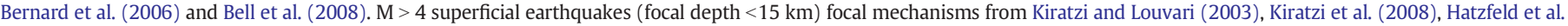
(1990), and RCMT catalogue (http://www.bo.ingv.it/RCMT/).

2008). This change has been attributed to a difference in the geology of the basement (Taylor et al., 2011). Isochores variations are not directly linked to tectonics here because of sediment transport from the shallower western to the deeper central Gulf (McNeill et al., 2005a). Consequently, the rift polarity of this part of the western sector is difficult to comprehend.

About $12 \mathrm{~km}$ west of the boundary between the Central and the Western Gulf, a major structural change occurs. The seafloor and Reflector 2 are subhorizontal, which suggests that the recent activity of faults bordering both the north and south sides of the Western Gulf is similar. The central part of Trizonia Island, located on the footwall of the Trizonia fault, is subsiding at $5 \pm 2 \mathrm{~mm} \mathrm{yr}^{-1}$ (GPS data; Bernard et al., 2006). This suggests that, though the Trizonia fault is an active structure, some deformation occurs north of this fault as well.

More to the west, we define the westernmost sector of the Gulf of Corinth (Fig. 15). In its eastern part, our data highlight the activity of the south-dipping Marathias fault and of the NW trending transtensive Managouli fault zone. The vertical movement resulting from the activity of the later fault, as well as its horizontal motion, is unknown. About the Marathias fault, InSAR data suggest that the onshore Marathias delta subsides by $3-5 \mathrm{~mm} \mathrm{yr}^{-1}$ (Elias, 2013). This value probably encompasses sediment compaction as well as tectonic subsidence. It is consequently compatible with our subsidence estimate of $2.6-3.6 \mathrm{~mm} \mathrm{yr}^{-1}$ over the last $11.5 \mathrm{ka}$. In this part of the rift, Late Quaternary sediments thicken to the south, indicating a larger subsidence induced by the Kamari fault system compared to the Marathias-Managouli faults (Fig. 10). A minimum estimate of slip rate of $1.9-2.7 \mathrm{~mm} \mathrm{yr}^{-1}$ for the last 2000 years has been proposed for the Selianitica scarp, located in the center of the Kamarai fault system (Palyvos et al., 2005). Subsidence rates associated to the Marathias fault are higher. This discrepancy may have several origins. First, the Kamarai fault slip rate is a minimum estimate and it was obtained on a relatively short timeperiod (Palyvos et al., 2005). Second, the comparison between the slip rates of the main $\mathrm{N}$-dipping and S-dipping faults in this part of the rift does not consider the influence of the Managouli fault zone, which is difficult to unravel.

The central part of the westernmost sector is affected by the Psathopyrgos fault. The rift polarity for the Late Quaternary is not constrained in this zone due to low penetration of the acoustic signal. West of the Psathopyrgos fault, fault strike changed from W-E to SW-NE, and strike-slip motion occurs on most of the mapped faults (Fig. 15). This radical change in the tectonic style is discussed in the next section.

In summary, in the western and the westernmost sectors of the Gulf of Corinth, the rift polarity or the structure of the rift active during the Late Quaternary change along strike over very short distances (Fig. 15). The fault network is highly segmented, the longest faults reaching $16 \mathrm{~km}$. This pattern is different from the central and eastern gulf, where the fault length reaches up to $35 \mathrm{~km}$ (e.g., the Derveni fault, Fig. 15). Besides, the westernmost sector is characterized by the occurrence of strike-slip motion. These observations indicate a less mature and younger fault system in the western and the westernmost sectors compared to the central and eastern sectors. The influence of a change in bedrock geology proposed by Taylor et al. (2011) may, however, not be rejected.

The documented surface fault pattern bears only little resemblance to the deep structure defined seismologically. In the Western Gulf, microseismicity is mostly concentrated in a layer that is gently dipping to the north between 5 and $10 \mathrm{~km}$ beneath the Gulf. The upper $4 \mathrm{~km}$ of the crust is characterized by a lack of seismicity, which makes the link between the surface faults and the deep structure quite speculative. One of the reference geodynamic models consists of steeply 


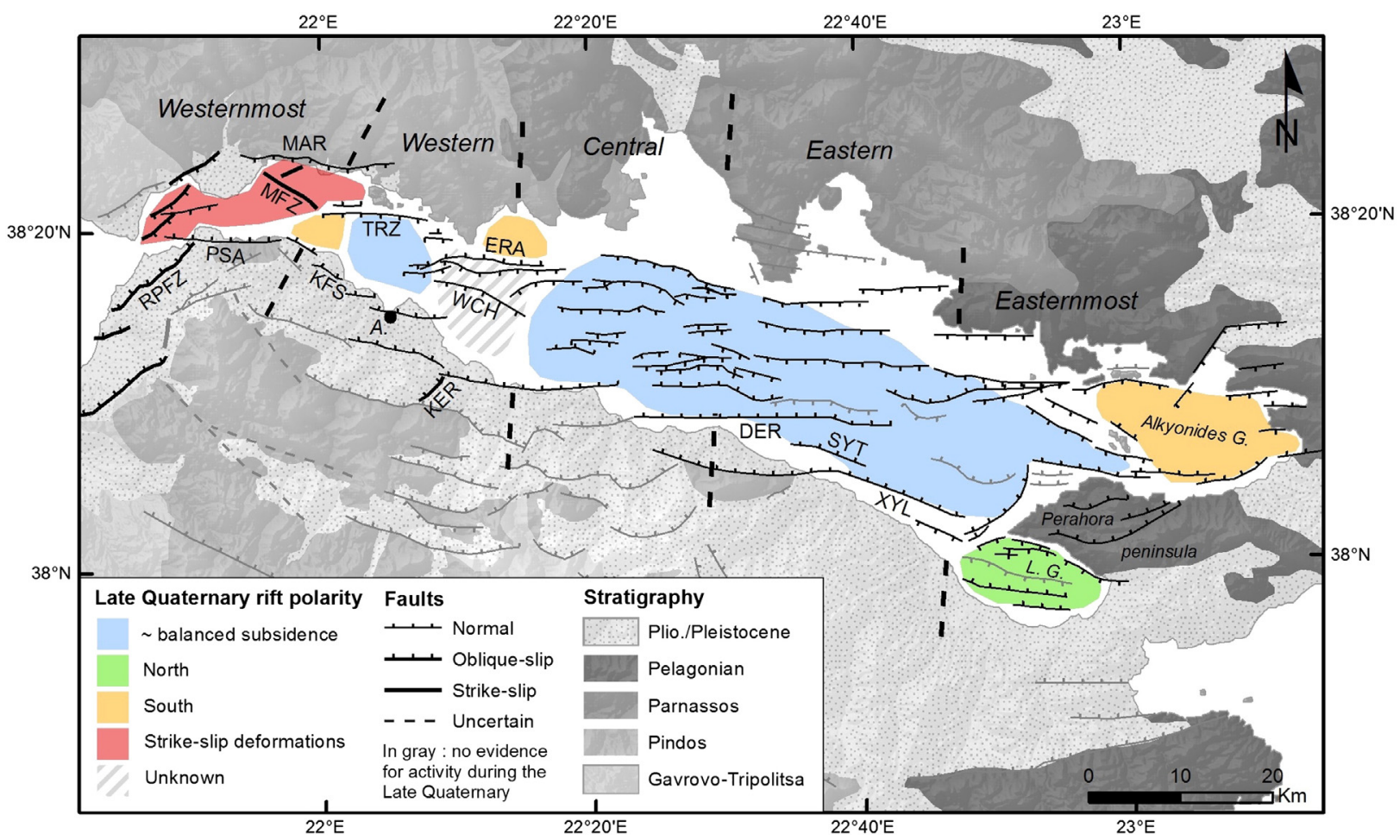

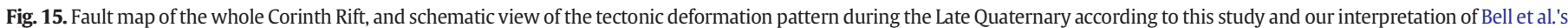

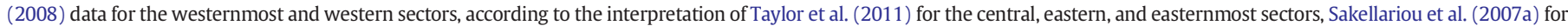

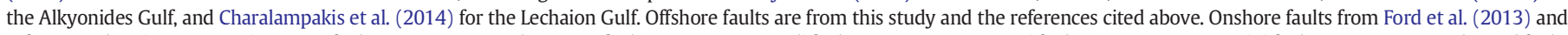

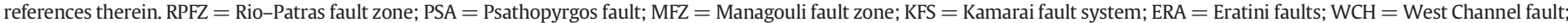
KER = Kerinitis fault; DER $=$ Derveni fault; SYT = Sytas fault; XYL = Xylocastro fault; A. = Aigion; L.G. = Lechaion Gulf.

north-dipping coastal or nearshore faults rooting into a flat or gently dipping structure beneath the Gulf (Bernard et al., 2006; Godano et al., 2014). Our observations seem in contradiction with the proposed asymmetrical rifting model. Indeed, a significant part of the deformation is accommodated on the faults in the northern part of the Gulf, i.e., the Trizonia, Managouli, and Marathias faults. In addition, the sedimentary infill in a wide area of the western segment of the Gulf is made of subhorizontal strata, suggesting a more symmetric rift structure (Fig. 15). Our data thus agree more with the alternative model of Lambotte et al. (2014). They propose a rifting model with a rather symmetrical ( " mode I ») NS-oriented opening, complemented by an early stage of a detachment, growing downdip toward the north (Godano et al., 2014; Lambotte et al., 2014). This very rapidly evolving tectonic system, interplaying the activity of old and of new, growing faults, would be driven by a dominantly axial strain source at mid-crustal depth. The model fits the geological, seismological, and geodetic data as well as the geophysical data of the present study.

5.3. Nafpaktos Basin: part of the triple junction between continental Greece, Peloponnese, and the Ionian Island-Akarnania blocks?

The NE-SW fault system of the Nafpaktos Basin is composed of two main offshore faults (F1, F3, Fig. 6), the coastal Nafpaktos fault and the onshore Rio-Patras fault zone (RPFZ). The NE-SW offshore faults accommodate right-lateral transtension. The onshore deformation pattern is similar (Fig. 14). InSAR data have documented creeping along the Nafpaktos fault with $\sim 2 \mathrm{~mm} \mathrm{yr}^{-1}$ normal motion and dextral motion as well (Elias, 2013). To the south, the RPFZ has a comparable deformation pattern. InSAR data suggest that the fault is creeping with about $4 \mathrm{~mm} \mathrm{yr}^{-1}$ normal slip and some right-lateral motion (Elias, 2013; Parcharidis et al., 2013). The strongest earthquake in the area was the $1993 M_{\mathrm{W}} 5.4$ Patras earthquake. It had a strike-slip mechanism, but the earthquake has been attributed to another fault, south and parallel to the RPFZ, the Saravali fault (Fig. 14, Tselentis, 1998). Therefore, in and around the Nafpaktos Basin, there are a set of five significant faults exhibiting right-lateral motion. At a larger scale, they form a leftstepping en-echelon system, which extends for about $36 \mathrm{~km}$ from the south coast of the Gulf of Patras (e.g., the Saravali fault) to the Mornos delta in the Gulf of Corinth (e.g., the Nafpaktos fault) (Fig. 14).

The documented strike-slip fault system reflects the diffuse deformation occurring at a triple junction between three distinct crustal blocks: Continental Greece to the north, the Peloponnese to the south, and the Ionian Island-Akarnania Block (IAB) to the west (Vassilakis et al., 2011; Perouse, 2013) (Fig. 14). The triple junction marks the intersection of the E-W Corinth Rift system to the east, with two antithetic strike-slip fault zones to the northwest and southwest. The strike-slip system to the northwest is composed of the N140-N155 KatounaStamna left-lateral fault (KSF; Perouse, 2013) and of a deformation zone around the Trichonis Basin (Kiratzi et al., 2008) (Fig. 14). The KSF is a major well-localized fault, active since about $\sim 1.5 \mathrm{Ma}$, and GPS data indicate a geodetic slip rate of about $10 \mathrm{~mm} \mathrm{yr}^{-1}$ (Perouse, 2013). The strike-slip system to the southwest is less well defined. It would correspond to the right-lateral NE-SW Achaia-Elia fault that has no surface expression (Feng et al., 2010). The fault activity is mainly attested by the $2008 M_{\mathrm{W}}$ 6.4 Achaia-Elia earthquake (Feng et al., 2010; Margaris et al., 2010). Within this geodynamic framework, the spatial arrangement of the faults showed in Fig. 14 indicates that the NE-SW Nafpaktos-Rio-Patras fault system would be linked to the right-lateral Achaia-Elia fault, and would represent the northernmost expression of the boundary between the Peloponnese and the IAB. This interpretation is based on the NE strike and on the strike-slip motion of the faults we have highlighted in the Napaktos Basin, combined with sparse data found in the literature about active faulting east and south of the Gulf of Patras that we have described in this section. More investigations are needed to prove the existence of this block boundary, as well as to prove the connection at depth between all these faults. 
Concerning the boundary between Continental Greece and the IAB, we did not find any evidence for NW-SE structures in the Nafpaktos Basin, which could accommodate some deformation in continuity with the left-lateral KSF and the Trichonis Basin (Fig. 14). Seismological data suggested that a NW-SE blind fault zone would link the Trichonis Graben to the Nafpaktos Basin (Kiratzi et al., 2008). The lack of surface expression of this system in the Nafpaktos Basin confirms that this junction between Continental Greece and the IAB is not yet a matured structure, as already suggested by Perouse (2013) and Vassilakis et al. (2011), and that we may have a decoupling between the near-surface deformation affecting the upper $5 \mathrm{~km}$ and the deep structure inferred from seismological data.

\subsection{Comparison between geodetic and long-term extension rates}

Based on the slip-rate data presented in this work for the Western Gulf, we compare the extension rate derived from fault slip rates to the geodetic one, along a SSW-NNE transect crossing Temeni (location of the village; Fig. 6). From north to south, the following active faults are crossed: West-Eliki, Aigion, F10, North Eratini, the northernmost horst-bounding faults, and a coastal fault. For the West-Eliki fault, we used the Late Quaternary uplift rate of $1.25 \mathrm{~mm} \mathrm{yr}^{-1}$ from De Martini et al. (2004) and the uplift-subsidence ratio of 1:1.2-2.2 estimated by McNeill et al. (2005b) for the East-Eliki fault to deduce a slip rate of $3.6-5.2 \mathrm{~mm} \mathrm{yr}^{-1}$. This is higher than the rate estimated from paleoseismology (0.3-2.0 $\mathrm{mm} \mathrm{yr}^{-1}$, Koukouvelas et al., 2005). The slip rate of the Aigion fault has been estimated at $3.5 \pm 1 \mathrm{~mm} \mathrm{yr}^{-1}$ by McNeill et al. (2007), in good agreement with results from paleoseismology (Pantosti et al., 2004), but lower than the estimates by dislocation modeling (De Martini et al., 2004). Slip rates for F10 and the western tip of the North Eratini faults come from this study (Table 1). For the two faults bounding the horst and the coastal fault, we assume a reasonable range of slip rates of $0.5-2 \mathrm{~mm} \mathrm{yr}^{-1}$ based on their small length $(<5 \mathrm{~km})$. Finally, a dip angle at depth of $60^{\circ}$ has been used for each fault (Bernard et al., 2006). The assessed extension rate ranges between 4.1 and $8.4 \mathrm{~mm} \mathrm{yr}^{-1}$. This is fairly comparable to the $5-14.5 \mathrm{~mm} \mathrm{yr}^{-1}$ assessed just $15 \mathrm{~km}$ to the east by Bell et al. (2008). However, it does not fully agree with the geodetic rate (10-16 $\mathrm{mm} \mathrm{yr}^{-1}$, Avallone et al., 2004). This kind of discrepancy has been discussed at the scale of the whole rift by Bell et al. (2011). Comparing GPS-derived extension rates with Late Quaternary summed fault displacements and total extension; they suggested that the difference between short-term and long-term patterns of extension is due to fault growth and linkage. Our profile is located at the western tip of a major fault system (the Eratini-West Channel fault system), where deformation is distributed partly on faults reaching the surface, but also on at least one active blind fault that do not cause detectable deformations of the offshore syn-rift sediments at shallow depth (the 1995 Aigion EQ fault, Bernard et al., 1997; McNeill et al., 2005a). The presence of this kind of faults could also explain the difference between the two estimates of extension rate. This is in accordance with Marrett and Allmendinger (1992), who suggested that as much as $25-60 \%$ of extension across a region occurs by faulting on small faults below seismic resolution.

\subsection{Seismic hazard}

The proposed new active faulting pattern has implications regarding seismic hazard assessment. In our study area, we have mapped numerous active faults with lengths greater than $6 \mathrm{~km}$ and slip rates larger than

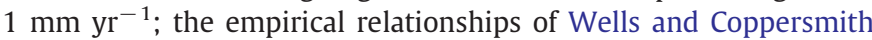
(1994) imply that they could rupture in $M_{\mathrm{W}} \geq 6$ earthquakes. In particular, we have reevaluated the length of the Psathopyrgos fault (12 km) bounding the rift to the south and highlight the importance of the Managouli $(7.5 \mathrm{~km})$, Marathias $(14 \mathrm{~km})$, and Trizonia $(10-11.5 \mathrm{~km})$ faults bounding the rift to the north. Considering that the fault length corresponds to the maximum expected earthquake rupture length,
Table 2

Length and estimated maximum credible earthquake magnitude for five faults for which this study present new data.

\begin{tabular}{lll}
\hline Fault name & $\begin{array}{l}\text { Length } \\
(\mathrm{km})\end{array}$ & $\begin{array}{l}\text { Range of estimated } M_{\mathrm{W}}( \pm 2 \sigma) \\
\text { (Wells and Coppersmith, 1994) }\end{array}$ \\
\hline Marathias & 14 & $6.0-6.8$ \\
Psathopyrgos & 12 & $5.9-6.7$ \\
Trizonia & $10-11.5$ & $5.9-6.7$ \\
Managouli & 7 & $5.7-6.5$ \\
F2 & 6 & $5.6-6.4$ \\
\hline
\end{tabular}

Table 2 shows possible earthquake magnitudes for these faults, according to the Wells and Coppersmith's (1994) regression. This table is not an exhaustive summary of the possible seismogenic faults in the study area. It comprises only faults for which this study has provided new data, either about fault activity (the Marathias fault), about fault length (the Psatopyrgos fault) or both (the Managouli fault zone and the Trizonia fault). Seismic hazard related to the other coastal faults has been studied by Boiselet (2014). Moreover, the last major EQs and the microseismicity have shown that the extension is accommodated on a large number of faults, and the last two major EQs in the Western Rift ruptured faults that are blind (i.e., Aigion 1995 EQ, Bernard et al., 1997) or were not described as a major structure before the earthquake (i.e., Efpalio sequence, Sokos et al., 2012). Consequently, numerous questions remain regarding the most appropriate way to assess seismic hazard in this area.

\section{Conclusion}

The present study provides an accurate map of offshore faults at the western end of the Gulf of Corinth and documents for the first time in the offshore Corinth Rift significant strike-slip motion, in addition to the dominant extensional strain. To the west, an oblique-slip, enechelon fault system has been identified in and around the Nafpaktos Basin. We suggest a connection with the right-lateral Achaia-Elia fault. The Nafpaktos basin could represent the northernmost expression of the boundary between the Peloponnese and the Ionian IslandAkarnania Block. To the east, the symmetric subsidence of the deep Gulf allows reconsidering the importance of south-dipping faults bounding the Rift to the north. Finally, the proposed new active faulting pattern has implications regarding seismic hazard assessment, with several active offshore and coastal faults potentially able to trigger $M_{\mathrm{W}} \geq 6$ earthquakes. The key remaining question would be to determine if these faults are locked, creeping or partially creeping.

\section{Acknowledgments}

This work has been funded within the ANR SISCOR project directed by Pascal Bernard, at Institut de Physique du Globe (Paris). Arnaud Beckers's PhD grant is supported by the Belgian FRIA. Funding for Arnaud Beckers' stays in the ISTerre Laboratory was provided by a grant from la Région Rhône-Alpes. The authors warmly acknowledge Rebecca Bell and an anonymous reviewer for their numerous and constructive remarks. The authors are also grateful to David Garcia Moreno (Royal Observatory of Belgium) for training in seismics interpretation. They warmly acknowledge R/V ALKYON's crew, Koen De Rycker (RCMG), and Pascale Bascou (ISTerre) for technical support, and the whole SISCOR scientific team for fruitful discussions.

\section{References}

Armijo, R., Meyer, B., King, G.C.P., Rigo, A., Papanastassiou, D., 1996. Quaternary evolution of the Corinth Rift and its implications for the Late Cenozoic evolution of the Aegean. Geophysical Journal International 126 (1), 11-53.

Armijo, R., Flerit, F., King, G., Meyer, B., 2004. Linear elastic fracture mechanics explains the past and present evolution of the Aegean. Earth and Planetary Science Letters $217(1-2), 85-95$. 
Avallone, A., Briole, P., Agatza-Balodimou, A.M., Billiris, H., Charade, O., Mitsakaki, C., Nercessian, A., Papazissi, K., Paradissis, D., Veis, G., 2004. Analysis of eleven years of deformation measured by GPS in the Corinth Rift Laboratory area. Comptes Rendus Geoscience 336, 301-311.

Beckers, A., Mortier, C., Beck, C., Hubert-Ferrari, A., Reyss, J.-L., Tripsanas, E., Sakellariou, D., De Batist, M., De Rycker, K., Bascou, P., Strivay, D., 2013. High energy environment offshore deposits in the western Gulf of Corinth, Greece. Geophysical Research Abstracts vol. 15 (EGU2013-4877, EGU General Assembly 2013).

Bell, R.E., 2008. Tectonic Evolution of the Corinth Rift. (PhD Thesis). University of Southampton.

Bell, R.E., McNeill, L.C., Bull, J.M., Henstock, T.J., 2008. Evolution of the offshore western Gulf of Corinth. Geological Society of America Bulletin 120 (1-2), 156-178.

Bell, R.E., McNeill, L.C., Bull, J.M., Henstock, T.J., Collier, R.E.L., Leeder, M.R., 2009. Fault architecture, basin structure and evolution of the Gulf of Corinth Rift, central Greece. Basin Research 21 (6), 824-855.

Bell, R.E., McNeill, L.C., Henstock, T.J., Bull, J.M., 2011. Comparing extension on multiple time and depth scales in the Corinth Rift, Central Greece. Geophysical Journal International 186, 463-470.

Bernard, P., Briole, P., Meyer, B., Lyon-Caen, H., Gomez, J.-M., Tiberi, C., Berge, C., Cattin, R., Hatzfeld, D., Lachet, C., Lebrun, B., Deschamps, A., Courboulex, F., Larroque, C., Rigo, A., Massonnet, D., Papadimitriou, P., Kassaras, J., Diagourtas, D., Makropoulos, K., Veis, G., Papazisi, E., Mitsakaki, C., Karakostas, V., Papadimitriou, E., Papanastassiou, D., Chouliaras, M., Stavrakakis, G., 1997. The Ms = 6.2, June 151995 Aigion earthquake (Greece): evidence for low angle normal faulting in the Corinth Rift. Journal of Seismology 1 (2), 131-150.

Bernard, P., Lyon-Caen, H., Briole, P., Deschamps, A., Boudin, F., Makropoulos, K. Papadimitriou, P., Lemeille, F., Patau, F., Billiris, H., Paradissis, D., Papazissi, K., Castarède, H., Charade, O., Nercessian, A., Avallone, A., Pacchiani, F., Zahradnik, J., Sacks, S., Linde, A., 2006. Seismicity, deformation and seismic hazard in the western rift of Corinth: new insights from the Corinth Rift Laboratory (CRL). Tectonophysics 426 (1-2), 7-30.

Boiselet, A., 2014. Cycle sismique et alea sismique d'un réseau de failles actives: le cas du rift de Corinthe (Grêce). (PhD Thesis). Ecole Normale Supérieure of Paris and IRSN.

Briole, P., Rigo, A., Lyon-Caen, H., Ruegg, J.C., Papazissi, K., Mitsakaki, C., Balodimou, A., Veis, G., Hatzfeld, D., Deschamps, A., 2000. Active deformation of the Corinth Rift, Greece: results from repeated global positioning system surveys between 1990 and 1995. Journal of Geophysical Research 105 (B11), 25605-25625.

Campos, C., Beck, C., Crouzet, C., Carrillo, E., Van Welden, A., Tripsanas, E., 2013. Late Quaternary paleoseismic sedimentary archive from deep central Gulf of Corinth: time distribution of inferred earthquake-induced layers. Annals of Geophysics 56 (6), S0670.

Charalampakis, M., Lykousis, V., Sakellariou, D., Papatheodorou, G., Ferentinos, G., 2014. The tectono-sedimentary evolution of the Lechaion Gulf, the south eastern branch of the Corinth Graben, Greece. Marine Geology. http://dx.doi.org/10.1016/j.margeo. 2014.03.014

Chronis, G., Piper, D.J.W., Anagnostou, C., 1991. Late Quaternary evolution of the Gulf of Patras, Greece: tectonism, deltaic sedimentation and sea-level change. Marine Geology 97, 191-209.

Collier, R.E., Dart, C.J., 1991. Neogene to Quaternary rifting, sedimentation and uplift in the Corinth Basin, Greece. Journal of the Geological Society 143 (6), 1049-1065.

Collier, R.E.L., Leeder, M.R., Trout, M., Ferentinos, G., Lyberis, E., Papatheodorou, G., 2000 High sediment yields and cool, wet winters: test of last glacial paleoclimates in the northern Mediterranean. Geology 28, 999-1002.

Cornet, F.H., Doan, M.L., Moretti, I., Borm, G., 2004. Drilling through the active Aigion Fault: the AIG10 well observatory. Comptes Rendus Geoscience 336 (4-5), 395-406.

Cotterill, C.J., 2006. A high-resolution Holocene fault activity history of the Aigion Shelf, Gulf of Corinth, Greece. (PhD Thesis). University of Southampton.

De Martini, P.M., Pantosti, D., Palyvos, N., Lemeille, F., McNeill, L., Collier, R., 2004. Slip rates of the Aigion and Eliki Faults from uplifted marine terraces, Corinth Gulf, Greece. Comptes Rendus Geoscience 336, 325-334.

Elias, P., 2013. Ground deformation observed in the western Corinth Rift (Greece) by means of SAR interferometry. (PhD Thesis). Ecole Normale Supérieure of Paris and University of Patras.

Feng, L., Newman, A.V., Farmer, G.T., Psimoulis, P., Stiros, S.C., 2010. Energetic rupture, coseismic and post-seismic response of the $2008 M_{W} 6.4$ Achaia-Elia Earthquake in northwestern Peloponnese, Greece: an indicator of an immature transform fault zone. Geophysical Journal International 183 (1), 103-110.

Ferentinos, G., Brooks, M., Doutsos, T., 1985. Quaternary tectonics in the Gulf of Patras, western Greece. Journal of Structural Geology 7, 713-717.

Flotté, N., Sorel, D., Müller, C., Tensi, J., 2005. Along strike changes in the structural evolution over a brittle detachment fault: example of the Pleistocene Corinth-Patras rift (Greece). Tectonophysics 403, 77-94.

Ford, M., Williams, E.A., Malartre, F., Popescu, S., 2009. Stratigraphic architecture, sedimentology and structure of the Vouraikos Gilbert-type fan delta, Gulf of Corinth, Greece. In: Nichols, G., Williams, E., Paola, C. (Eds.), Sedimentary Processes, Environments and Basins: A Tribute to Peter Friend. Blackwell Publishing Ltd, Oxford.

Ford, M., Rohais, S., Williams, E.A., Bourlange, S., Jousselin, D., Backert, N., Malartre, F., 2013. Tectono-sedimentary evolution of the western Corinth Rift (Central Greece). Basin Research 25 (1), 3-25.

Gallousi, C., Koukouvelas, I.K., 2007. Quantifying geomorphic evolution of earthquaketriggered landslides and their relation to active normal faults. An example from the Gulf of Corinth, Greece. Tectonophysics 440 (1-4), 85-104.

Godano, M., Deschamps, A., Lambotte, S., Lyon-Caen, H., Bernard, P., Pacchiani, F., 2014 Focal mechanisms of earthquake multiplets in the western part of the Corinth Rift (Greece): influence of the velocity model and constraints on the geometry of the active faults. Geophysical Journal International 197, 1660-1680. http://dx.doi.org/ $10.1093 /$ gji/ggu059.
Hatzfeld, D., Pedotti, G., Hatzidimitriou, P., Makropoulos, K., 1990. The strain pattern in the western Hellenic arc deduced from a microearthquake survey. Geophysical Journal International 101, 181-202.

Hatzfeld, D., Karakostas, V., Ziazia, M., Kassaras, I., Papadimitriou, E., Makropoulos, K., Voulgaris, N., Papaioannou, C., 2000. Microseismicity and faulting geometry in the Gulf of Corinth (Greece). Geophysical Journal International 141 (2), 438-456.

Heezen, B.C., Ewing, M., Johnson, G.L., 1966. The Gulf of Corinth floor. Deep-Sea Research 13, 381-411.

Hubert-Ferrari, A., King, G., Manighetti, I., Armijo, R., Meyer, B., Tapponnier, P., 2003. Longterm elasticity in the continental lithosphere; modelling the Aden Ridge propagation and the Anatolian extrusion process. Geophysical Journal International 153 (1), 111-132.

Jolivet, L., 2001. A comparison of geodetic and finite strain pattern in the Aegean geodynamic implications. Earth and Planetary Science Letters 187 (1-2), 95-104.

Jolivet, L., Labrousse, L., Agard, P., Lacombe, O., Bailly, V., Lecomte, E., Mouthereau, F., Mehl C., 2010. Rifting and shallow-dipping detachments, clues from the Corinth Rift and the Aegean. Tectonophysics 483, 287-304.

Kiratzi, A., Louvari, E., 2003. Focal mechanisms of shallow earthquakes in the Aegean Sea and the surrounding lands determined by waveform modeling: a new database. Journal of Geodynamics 36, 251-274.

Kiratzi, A., Sokos, E., Ganas, A., Tselentis, A., Benetatos, C., Roumelioti, Z., Serpetsidaki, A. Andriopoulos, G., Galanis, O., Petrou, P., 2008. The April 2007 earthquake swarm near Lake Trichonis and implications for active tectonics in western Greece. Tectonophysics 452 (1-4), 51-65.

Kokkalas, S., Xypolias, P., Koukouvelas, I., Doutsos, T., 2006. Postcollisional contractional and extensional deformation in the Aegean region. Special Paper of the Geological Society of America 409, 97-123.

Kontopoulos, N., Doutsos, T., 1985. Sedimentology and tectonics of the Antirion area (Western Greece). Bollettino della Societa Geologica Italiana 1, 479-489.

Koukouvelas, I.K., Stamatopoulos, L., Katsonopoulou, D., Pavlides, S., 2001. A palaeoseismological and geoarchaeological investigation of the Eliki fault, Gulf of Corinth, Greece. Journal of Structural Geology 23, 531-543.

Koukouvelas, I.K., Katsonopoulou, D., Soter, S., Xypolias, P., 2005. Slip rates on the Helike Fault, Gulf of Corinth, Greece: new evidence from geoarchaeology. Terra Nova 17 158-164.

Koukouvelas, I.K., Kokkalas, S., Xypolias, P., 2008. Paleoseismic investigations along a key active fault within the Gulf of Corinth, Greece. IOP Conference Series: Earth and Environmental Science 2. http://dx.doi.org/10.1088/1755-1307/2/1/012023.

Lambotte, S., Lyon-Caen, H., Bernard, P., Deschamps, A., Patau, G., Nercessian, A., Pacchiani, F., Bourouis, S., Drilleau, M., Adamova, P., 2014. Reassessment of the rifting process in the Western Corinth Rift from relocated seismicity. Geophysical Journal International 197, 1822-1844.

Leeder, M.R., Harris, T., Kirkby, M.J., 1998. Sediment supply and climate change: implications for basin stratigraphy. Basin Research 10 (1), 7-18.

Leeder, M.R., Collier, R.E.L., Abdul Aziz, L.H., Trout, M., Ferentinos, G., Papatheodorou, G., Lyberis, E., 2002. Tectono- sedimentary processes along an active marine/lacustrine half-graben margin: Alkyonides Gulf, E. Gulf of Corinth, Greece. Basin Research 14, 25-42.

Leeder, M.R., Portman, C., Andrews, J.E., Collier, R.E.L., Finch, E., Gawthorpe, R.L., McNeill, L.C., Pérez-Arlucea, M., Rowe, P., 2005. Normal faulting and crustal deformation, Alkyonides Gulf and Perachora peninsula, eastern Gulf of Corinth Rift, Greece. Journal of the Geological Society 162 (3), 549-561.

Lemeille, F., Chatoupis, F., Foumelis, M., Rettenmaier, D., Unkel, I., Micarelli, L., Moretti, I., Bourdillon, C., Guernet, C., Müller, C., 2004. Recent syn-rift deposits in the hangingwall of the Aigion Fault (Gulf of Corinth, Greece). Comptes Rendus Geoscience 336 (4-5), 425-434.

Li, X., Bell, R.E., Wrona, T., Rodriguez, C., 2014. Drilling a virtual core in the Gulf of Corinth. MAGELLAN Plus and NERC Funded IODP Proposal Planning Workshop, Anavyssos, Greece.

Lykousis, V., Sakellariou, D., Moretti, I., Kaberi, H., 2007a. Late Quaternary basin evolution of the Gulf of Corinth: sequence stratigraphy, sedimentation, fault-slip and subsidence rates. Tectonophysics 440 (1-4), 29-51.

Lykousis, V., Sakellariou, D., Rousakis, G., Alexandri, S., Kaberi, H., Nomikou, P., Georgiou, P., Balas, P., 2007b. Sediment failure processes in active grabens: the Western Gulf of Corinth (Greece). In: Lykousis, V., Sakellariou, D., Locat, J. (Eds.), Advances in Natural and Technological Hazards Research 27. Springer, pp. 297-305.

Lyon-Caen, H., Papadimitriou, P., Deschamps, A., Bernard, P., Makropoulos, K., Pacchiani, F., Patau, G., 2004. First results of the CRLN seismic network in the western Corinth Rift: evidence for old-fault reactivation. Comptes Rendus Geoscience 336 (4-5), 343-351.

Margaris, B., Athanasopoulos, G., Mylonakis, G., Papaioannou, C., Klimis, N., Theodulidis, N., Savvaidis, A., Efthymiadou, V., Stewart, J.P., 2010. The 8 June 2008 Mw6.5 Achaia-Elia, Greece Earthquake: source characteristics, ground motions, and ground failure. Earthquake Spectra 26 (2), 399-424.

Marrett, R., Allmendinger, R.W., 1992. Amount of extension on "small" faults: an example from the Viking graben. Geology 20, 47-50.

McNeill, L.C., Collier, R.E.L., 2004. Uplift and slip rates of the Eastern Eliki fault segment, Gulf of Corinth, Greece, inferred from Holocene and Pleistocene terraces. Journal of the Geological Society 161, 81-92.

McNeill, L.C., Cotterill, C.J., Henstock, T.J., Bull, J.M., Stefatos, A., Collier, R.E.L., Papatheoderou, G., Ferentinos, G., Hicks, S.E., 2005a. Active faulting within the offshore western Gulf of Corinth, Greece: implications for models of continental rift deformation. Geology 33 (4), 241.

McNeill, L.C., Collier, R.E.L., De Martini, P.M., Pantosti, D., D'Addezio, G., 2005b. Recent history of the Eastern Eliki Fault, Gulf of Corinth: geomorphology, palaeoseismology and impact on palaeoenvironments. Geophysical Journal International 161 (1), 154-166. 
McNeill, L.C., Cotterill, C.J., Bull, J.M., Henstock, T.J., Bell, R., Stefatos, A., 2007. Geometry and slip rate of the Aigion fault, a young normal fault system in the western Gulf of Corinth. Geology 35 (4), 355-358.

Moretti, I., Sakellariou, D., Lykousis, V., Micarelli, L., 2003. The Gulf of Corinth: an active half graben? Journal of Geodynamics 36 (1-2), 323-340.

Moretti, I., Lykousis, V., Sakellariou, D., Reynaud, J.-Y., Benziane, B., Prinzhoffer, A., 2004. Sedimentation and subsidence rate in the Gulf of Corinth: what we learn from the Marion Dufresne's long-piston coring. Comptes Rendus Geoscience 336 (4-5) 291-299.

Nomikou, P., Alexandri, M., Lykousis, V., Sakellariou, D., Ballas, D., 2011. Swath Bathymetry and Morphological Slope Analysis of the Corinth Gulf. 2nd INQUA-IGCP-567 International Workshop on Active Tectonics, Earthquake Geology, Archaeology and Engineering. Corinth, Greece, pp. 155-158.

Ori, G.G., 1989. Geologic history of the extensional basin of the gulf of Corinth (?MiocenePleistocene), Greece. Geology 17, 918-921.

Pacchiani, F., Lyon-Caen, H., 2010. Geometry and spatio-temporal evolution of the 2001 Agios Ioanis earthquake swarm (Corinth Rift, Greece). Geophysical Journal International 180, 59-72.

Palyvos, N., Pantosti, D., De Martini, P.M., Lemeille, F., Sorel, D., Pavlopoulos, K., 2005. The Aigion-Neos Erineos coastal normal fault system (western Corinth Gulf Rift, Greece): geomorphological signature, recent earthquake history, and evolution. Journal of Geophysical Research 110 (B9), B09302.

Palyvos, N., Lemeille, F., Sorel, D., Pantosti, D., Pavlopoulos, K., 2008. Geomorphic and biological indicators of paleoseismicity and Holocene uplift rate at a coastal norma fault footwall (western Corinth Gulf, Greece). Geomorphology 96 (1-2), 16-38.

Pantosti, D., De Martini, P.M., Koukouvelas, I., Stamatopoulos, L., Palyvos, N., Pucci, S. Lemeille, F., Pavlides, S., 2004. Palaeoseismological investigations of the Aigion Fault (Gulf of Corinth, Greece). Comptes Rendus Geoscience 336, 335-342.

Parcharidis, I., Kourkouli, P., Karymbalis, E., Foumelis, M., Karathanassi, V., 2013. Time series synthetic aperture radar interferometry for ground deformation monitoring over a small scale tectonically active deltaic environment (Mornos, Central Greece). Journal of Coastal Research 29 (2), 325-338.

Perouse, E., 2013. Cinématique et tectonique active de l'Ouest de la Grèce dans le cadre géodynamique de la Méditerranée Centrale et Orientale. (PhD Thesis). Université Orsay - Paris Sud, Paris XI.

Pérouse, E., Chamot-Rooke, N., Rabaute, A, Briole, P. Jouanne, F, Georgiev, I, Dimitrov, D. 2012. Bridging onshore and offshore present-day kinematics of central and eastern Mediterranean: implications for crustal dynamics and mantle flow. Geochemistry Geophysics, Geosystems 13 (9), Q09013.

Piper, D.J.W., Kontopoulos, N., Anagnostou, C., Chronis, G., Panagos, A.G., 1990. Modern Fan Deltas in the Western Gulf of Corinth, Greece. Geo-Marine Letters 10, 5-12.

Reilinger, R., McClusky, S., Paradissis, D., Ergintav, S., Vernant, P., 2010. Geodetic constraints on the tectonic evolution of the Aegean region and strain accumulation along the Hellenic subduction zone. Tectonophysics 488 (1-4), 22-30.

Rigo, A., Lyon-Caen, H., Armijo, R., Deschamps, A., Hatzfeld, D., Makropoulos, K. Papadimitriou, P., Kassaras, I., 1996. A microseismic study in the western part of the gulf of Corinth (Greece): implications for large-scale normal faulting mechanisms. Geophysical Journal International 126, 663-688.
Rohais, S., Eschard, R., Ford, M., Guillocheau, F., Moretti, I., 2007. Stratigraphic architecture of the pliopleistocene infill of the Corinth Rift: implications for its structural evolution. Tectonophysics 440, 5-28.

Sakellariou, D., Lykousis, V., Papanikolaou, D., 2001. Active faulting in the gulf of Corinth, Greece. Rapport Commission International Mer Mediterranee 36, 43.

Sakellariou, D., Lykousis, V., Alexandri, S., Rousakis, G., Nomikou, P., Georgiou, P., Ballas, D., 2007a. Faulting, seismic-stratigraphic architecture and later quaternary evolution of the Gulf of Alkyonides basin. Basin Research 19, 273-295.

Sakellariou, D., Lykousis, V., Alexandri, M., Rousakis, G., Georgiou, P., Nomikou, E., Ballas, D., Pampidis, I., Mantopoulos, P., 2007b. Technical report: 3HAZ CORINTH, D31, Map of offshore resent fault scarps vol. 004043 (Athens).

Sakellariou, D., Lykousis, V., Rousakis, G., 2011. Holocene seafloor faulting in the gulf of Corinth: the potential for underwater paleoseismology. 2nd INQUA-IGCP-567 International Workshop on Active Tectonics, Earthquake Geology, Archaeology and Engineering. Corinth, Greece, pp. 218-221.

Sokos, E., Zahradník, J., Kiratzi, A., Janský, J., Gallovič, F., Novotny, O., Kostelecký, J., Serpetsidaki, A., Tselentis, G.-A., 2012. The January 2010 Efpalio earthquake sequence in the western Corinth Gulf (Greece). Tectonophysics 530-531, 299-309.

Sorel, D., 2000. A Pleistocene and still-active detachment fault and the origin of the Corinth-Patras rift, Greece. Geology 28, 83-86.

Stefatos, A., Papatheodorou, G., Ferentinos, G., Leeder, M., Collier, R., 2002. Seismic reflection imaging of active offshore faults in the Gulf of Corinth: their seismotectonic significance. Basin Research 14 (4), 487-502.

Taylor, B., Weiss, J.R., Goodliffe, A.M., Sachpazi, M., Laigle, M., Hirn, A., 2011. The structures, stratigraphy and evolution of the Gulf of Corinth Rift, Greece. Geophysical Journal International 185 (3), 1189-1219.

Tselentis, G.-A., 1998. Fault lengths during the Patras 1993 earthquake sequence as estimated from the pulse width of initial P wave. Pure and Applied Geophysics 152 (1), 75-89.

Van Daele, M., van Welden, A., Moernaut, J., Beck, C., Audemard, F.A., Sanchez, J., Jouanne, F., Carrillo, E., Malavé, G., Lemus, A., De Batist, M., 2011. Reconstruction of Late Quaternary sea- and lake-level changes in a tectonically active marginal basin using seismic stratigraphy: the Gulf of Cariaco, NE Venezuela. Marine Geology 279 (1-4), 37-51.

Van Welden, A., 2007. Enregistrements sédimentaires imbriqués d'une activité sismique et de changements paléo-environnementaux. Etude comparée de différents sites : Golfe de Corinthe (Grèce), Lac de Shkodra (Alabanie/Montenegro), Golfe de Cariaco (Vénézuela). (PhD Thesis). Université de Savoie.

Vassilakis, E., Royden, L., Papanikolaou, D., 2011. Kinematic links between subduction along the Hellenic trench and extension in the Gulf of Corinth, Greece: A multidisciplinary analysis. Earth and Planetary Science Letters 303 (1-2), 108-120.

Waelbroeck, C., Labeyrie, L., Michel, E., Duplessy, J.C., McManus, J.F., Lambeck, K., Balbon, E., Labracherie, M., 2002. Sea-level and deep water temperature changes derived from benthic foraminifera isotopic records. Quaternary Science Reviews 21 (1-3), 295-305.

Wells, D.L., Coppersmith, K.J., 1994. New empirical relationships among magnitude, rupture length, rupture width, rupture area, and surface displacement. Bulletin of the Seismological Society of America 84 (4), 974-1002. 